Review

\title{
Ruthenium-Catalyzed C-H Activations for the Synthesis of Indole Derivatives
}

\author{
Haoran Zhu ${ }^{1,2}$, Sen Zhao ${ }^{1}$, Yu Zhou ${ }^{1,2}$, Chunpu Li ${ }^{1,2, *}$ and Hong Liu ${ }^{1,2, *}$ \\ 1 State Key Laboratory of Drug Research, Shanghai Institute of Materia Medica, Chinese Academy of Sciences, \\ 555 Zu Chong Zhi Road, Shanghai 201203, China; s18-zhuhaoran@simm.ac.cn (H.Z.); \\ zhaosenwj@163.com (S.Z.); zhouyu@simm.ac.cn (Y.Z.) \\ 2 School of Pharmacy, University of Chinese Academy of Sciences, No.19A Yuquan Road, \\ Beijing 100049, China \\ * $\quad$ Correspondence: lichunpu@simm.ac.cn (C.L.); hliu@simm.ac.cn (H.L.)
}

Received: 15 September 2020; Accepted: 23 October 2020; Published: 29 October 2020

check for updates

\begin{abstract}
The synthesis of substituted indoles has received great attention in the field of organic synthesis methodology. $\mathrm{C}-\mathrm{H}$ activation makes it possible to obtain a variety of designed indole derivatives in mild conditions. Ruthenium catalyst, as one of the most significant transition-metal catalysts, has been contributing in the synthesis of indole scaffolds through $\mathrm{C}-\mathrm{H}$ activation and $\mathrm{C}-\mathrm{H}$ activation on indoles. Herein, we attempt to present an overview about the construction strategies of indole scaffold and site-specific modifications for indole scaffold via ruthenium-catalyzed C-H activations in recent years.
\end{abstract}

Keywords: ruthenium; C-H activation; indole

\section{Introduction}

Substituted indoles are omnipresent in pharmaceutical industry. Some of them are the most sold drugs worldwide, presenting extraordinary efficacy in anti-cancer [1-5], sexual health [6], or anti-genetic disorders [7]. The indole containing compounds also exhibit wide range of pharmacological activity in bench work, such as antihistaminic, antimicrobial, anti-HIV, anti-inflammatory, and analgesic, as well as, anti-SARS-CoV-2 [8]. In natural products and marine compounds, indole moieties are also widely prevalent [9]. The interesting biological activities and structural features of substituted indoles have attracted intensive attention. Thus, the synthesis of substituted indoles has received great interest.

Since the beginning of 19th century, researchers, some of whom were written about in textbooks, have made great contributions for the synthesis of indole scaffolds. However, most of these reactions require well designed, uneasily synthesized, and relatively unstable substrates or harsh conditions, such as Fischer indole synthesis, Bartoli indole synthesis, and Hinsberg indole synthesis, suffering from poor functional group tolerance and limited substrate scopes [10].

Transition-metal-catalyzed direct $\mathrm{C}-\mathrm{H}$ activation would eliminate the need for prefunctionalization of substrates. Obviously, the direct $\mathrm{C}-\mathrm{H}$ activation would provide convenient methods for the synthesis of functionalized organic molecules. Recently, transition-metal-catalyzed $\mathrm{C}-\mathrm{H}$ activation has been well studied and established for the synthesis of indole scaffold compounds [11]; especially, the use of more stable and easy-to-handle ruthenium catalysts has tremendously contributed to the discovery of novel and efficient catalytic systems. The success of ruthenium catalysts is likely ascribed to their easy transformation into cyclometalated species via CMD (concerted metalation/deprotonation) process, their compatibility with frequently-used oxidants, and the stability to air or water. Within the last few years, the use of ruthenium catalysts has promoted the discovery of $\mathrm{C}-\mathrm{H}$ activation processes. It is the objective of this review to show the progressive discoveries of ruthenium-catalyzed C-H activations 
for the synthesis of indole derivatives. The current review will focus on indole scaffold construction and site-specific modifications via ruthenium-catalyzed $\mathrm{C}-\mathrm{H}$ activations.

\section{Indole Scaffold Construction via Ruthenium-Catalyzed C-H Activation}

Recently, transition-metal-catalyzed carbenoid insertion has been developed as a widely used tool to form $\mathrm{C}-\mathrm{C}$ bond. Li's group [12] reported the facile construction of 3-substituted $\mathrm{NH}$ indoles and 2,3-disubstituted $3 \mathrm{H}$-indoles by $\mathrm{Ru}(\mathrm{II})$-catalyzed $\mathrm{C}-\mathrm{H}$ activation of imidamides with diazo compounds, which enabled the synthesis of two kinds of substituted indoles by $[4+1]$ annulation (Scheme 1). On condition $\mathrm{A},\left[\mathrm{RuCl}_{2} \text { (p-cymene) }\right]_{2}$ was used to catalyze with $\mathrm{AgSbF}_{6}$ added additionally, the transformation of $\alpha \alpha$-diazoketoesters to form C-3-substituted indoles. When changing the diazo substrate into $\alpha \alpha$-diazomalonate, $3 \mathrm{H}$-indoles were given as the designed product with $\left[\mathrm{Ru}(p\right.$-cymene $)\left(\mathrm{MeCN}_{3}\right]\left(\mathrm{SbF}_{6}\right)_{2}$ participated as catalyst. They also proposed the possible mechanism of the process (Scheme 2). A CMD process is conducted to afford the metalacyclic intermediate A with the cyclometallation of the imidamides. Then, $\alpha \alpha$-diazoketoesters or $\alpha \alpha$-diazomalonate is coordinate to the intermediate $\mathrm{A}$ before denitrogenation to generate ruthenium carbene species $\mathrm{B}$. Then the seven-membered ruthenacyclic intermediate $C$ is furnished with the migratory insertion of the ruthenium-aryl bond. After that, intermediate $\mathrm{D}$ is then formed by Ru-C(alkyl) migratory insertion into the $\mathrm{C}=\mathrm{N}$ bond. For diazoketoester substrates, protonolysis and intramolecular nucleophilic addition and subsequent elimination of one molecule of $\mathrm{NH}$ amide is conducted with $\mathrm{NH}$-indole product 3 eventually released from $\mathrm{D}$. For diazomalonates, the intermediate $\mathrm{D}$ undergoes elimination of ammonia with assistance of $\mathrm{Ru}(\mathrm{II})$ or acetic acid, forming $3 \mathrm{H}$-indole $\mathbf{5}$ as the final product. This reaction constitutes the first intermolecular coupling of arenes with diazo substrates by ruthenium-catalyzed $\mathrm{C}-\mathrm{H}$ activation, which may lead to applications in the discovery of bioactive compounds with medium to good yields.<smiles>[R]OC(=O)c1c(C)[nH]c2ccc([R])cc12</smiles>

(Conditions A)

$\mathrm{R}^{\prime}=\mathrm{H}$, alkyl, halogen, $\mathrm{CO}_{2} \mathrm{Me}, \mathrm{CF}_{3}, \mathrm{NO}_{2}, \mathrm{CN}, \ldots$

$55 \%-96 \%$ yields $\mathrm{R}=\mathrm{Et}, \mathrm{Me}, t-\mathrm{Bu} \ldots$

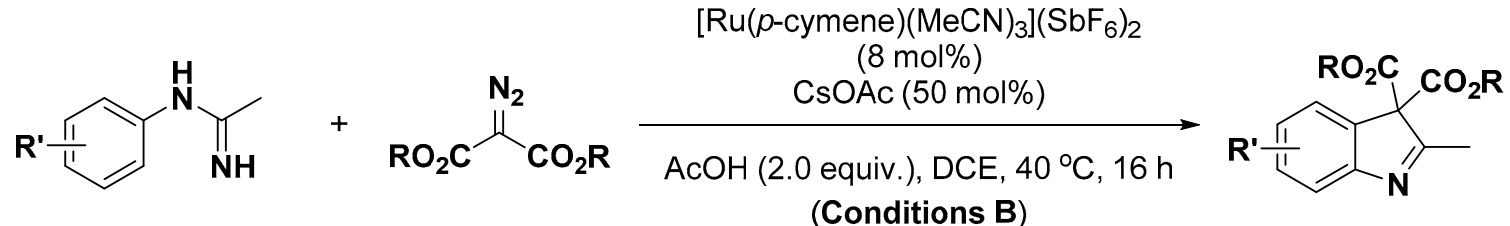

(Conditions B)

$\mathrm{R}^{\prime}=\mathrm{H}$, alkyl, halogen, $\mathrm{CO}_{2} \mathrm{Me}, \mathrm{CN}, \mathrm{CF}_{3}, \mathrm{OCF}_{3}, \mathrm{NO}_{2}, \mathrm{MeO} \ldots$ $\mathrm{R}=\mathrm{Et}, \mathrm{Me}, t-\mathrm{Bu}, \mathrm{Bn} .$.

$40 \%-75 \%$ yields

Scheme 1. Ru-catalyzed C-H activation for the synthesis of 3-substituted indoles or 3,3-disubstituted indoles. 


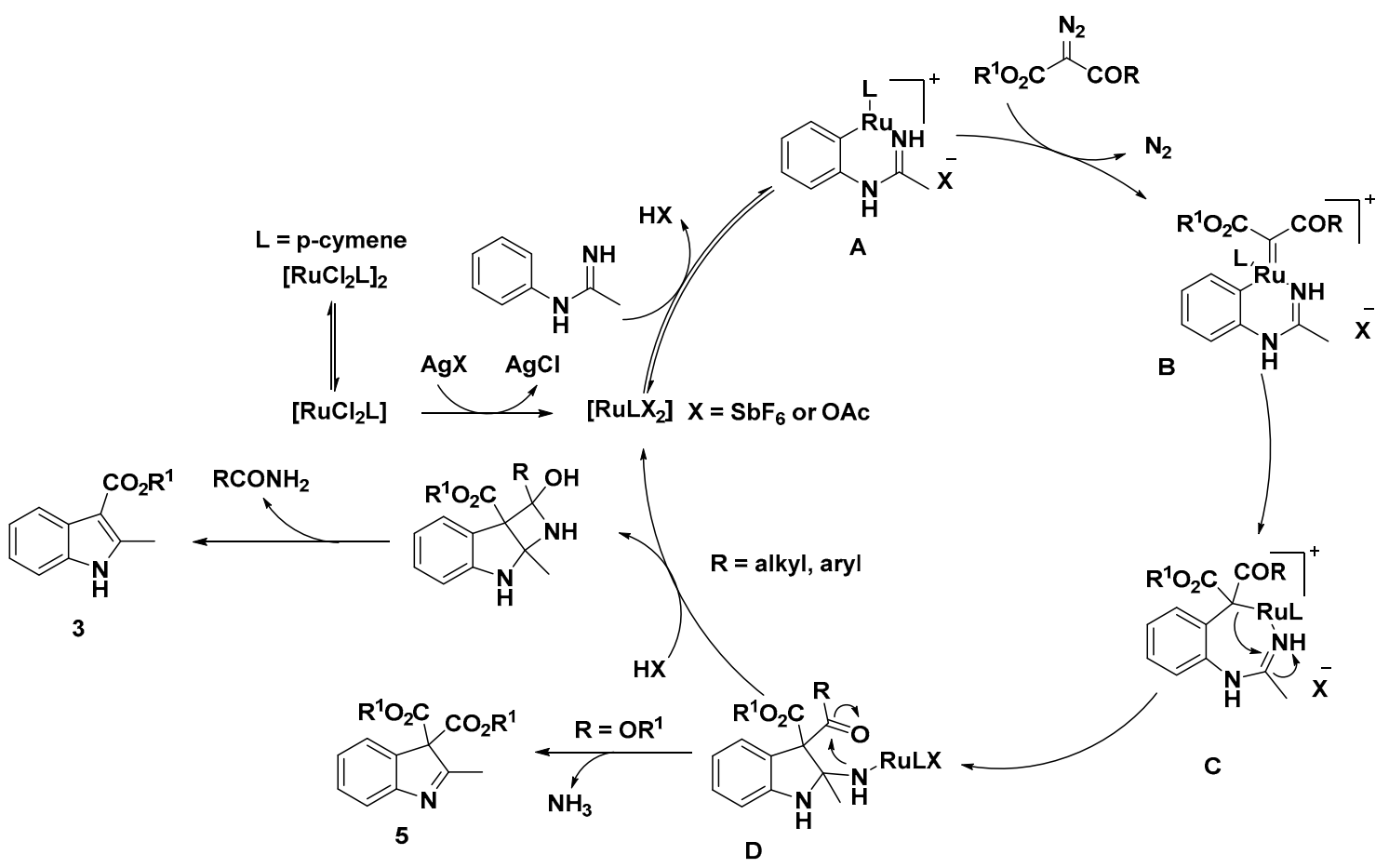

Scheme 2. Proposed reaction mechanism.

Inspired by the high reactivity of diazo compounds, our group [13] developed a highly efficient synthetic strategy to construct 3-phosphorylindole scaffolds via selective reversible $\mathrm{C}-\mathrm{H}$ bond activations of $\mathrm{N}$-phenylbenzimidamide, and the subsequent divergent couplings with diazophosphonate compounds were achieved successfully with $\mathrm{Ru}$ (II) catalyst systems (Scheme 3). The yields of the examples are $60-90 \%$.

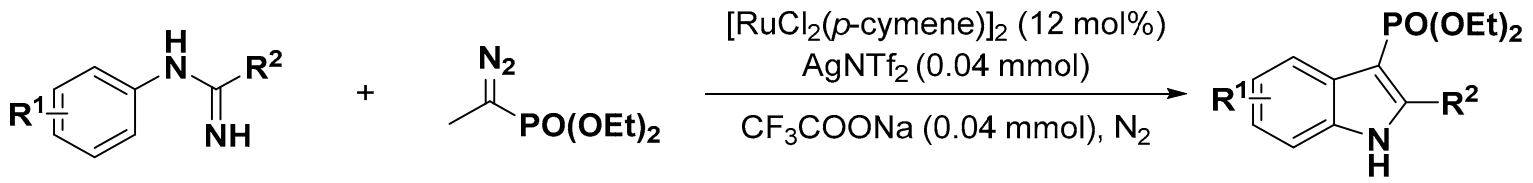

$\mathrm{R}^{1}=\mathrm{H}, \mathrm{OMe}$, halogen, $\mathrm{CN} \ldots$

$\mathrm{R}^{2}=\mathrm{Ph}, \mathrm{MePh}, \mathrm{CIPh}, \mathrm{CF}_{3} \mathrm{Ph} \ldots$

up to $86 \%$ yields

Scheme 3. Carbene insertion reaction to afford phosphorous indoles.

Alkynes are now a developing sorts of coupling partners to construct divergent scaffolds. Recently, Rh-catalyzed and Pd-catalyzed C-H activation leading to the construction of indoles with alkynes have emerged as a powerful strategy. In addition, Ru-catalyzed C-H activation for the synthesis of indole scaffolds using alkynes as substrates has attracted much attention due to the high efficiency (Scheme 4). In 2012, Ackermann's group [14], based on their previous work and experience on heterocycle construction, achieved [3+2] annulation of anilines bearing removable pyrimidyl group as directing group, which led to the formation of 2,3-disubstituted indoles, with the use of the most applied cationic ruthenium complex $\left[\mathrm{RuCl}_{2}(p \text {-cymene) }]_{2}\right.$ as catalyst. The reaction conducting $\mathrm{C}-\mathrm{H} / \mathrm{N}-\mathrm{H}$ bonds cleavage efficiently occurs in water as a sustainable solvent. The initiation of the proposed catalytic cycle is the reversible cyclometallation with cationic ruthenium complex to form the key intermediate, a six-membered ruthenacycle. Then, the complex undergoes coordination and migratory insertion with the alkyne followed to furnish ruthacycle. At last, the desired product is given by reductive elimination. The scope of the substrates has a wide range. Examples, including electron-donating groups, such as the methyl group, and electron-withdrawing groups, such as the trifluoromethyl 
group, on the benzene are well tolerated in this method, as well as aromatic or alkyl alkynes. The catalytically active cationic complex is regenerated with reoxidation. In 2017, Cai [15] reported a similar method using PEG400/water as solvent to provide a sustainable way to achieve indole derivatives. Notably, the catalyst can be recycled in this catalytic system. In addition, Kumara [16] and his coworkers described a similar Ru-catalyzed [3+2] annulation of 6-anilinopurines with internal alkynes, giving indole-substituted purine nucleobases. In this work, a ruthenacycle intermediate was characterized indicating that the N-1 nitrogen atom of the purine acts as a directing group for this transformation.

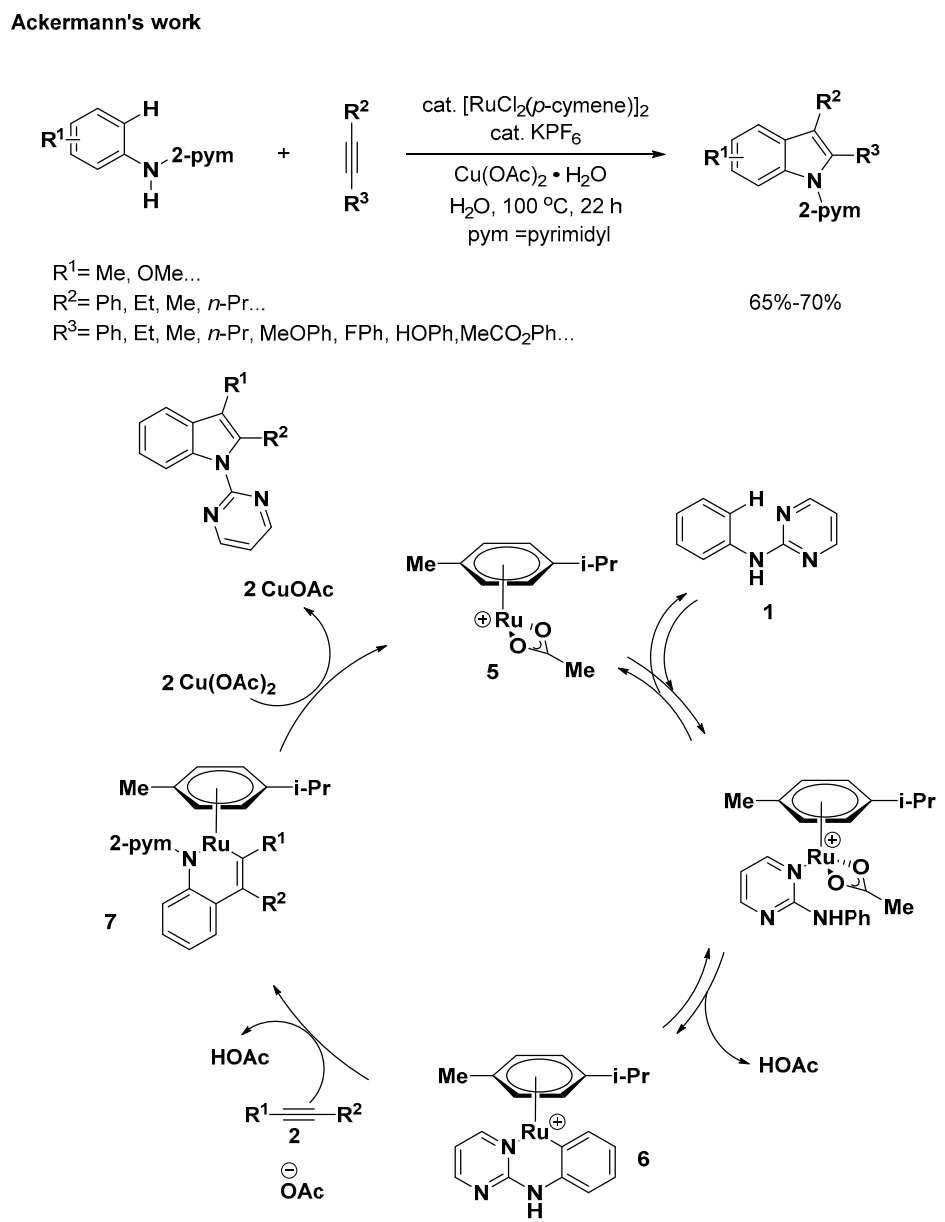

Cai's work
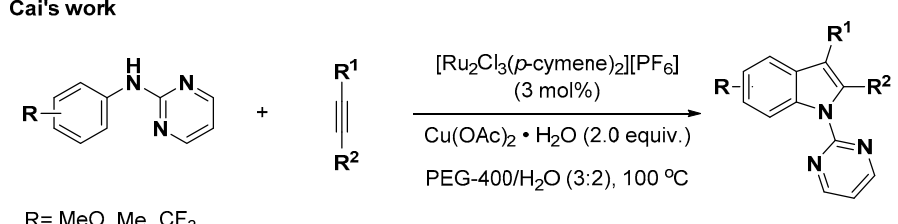

$\mathrm{R}=\mathrm{MeO}, \mathrm{Me}, \mathrm{CF}_{3} \ldots$
$\mathrm{R}_{1}=\mathrm{Me}, \mathrm{Et}, n-\mathrm{Bu}, \mathrm{Ph}$

$\mathrm{R}_{2}=\mathrm{MeO}, \mathrm{Et}, \mathrm{Ph}, \mathrm{pMeOPh}, \mathrm{pOHPh} .$.

$69 \%-94 \%$ yields

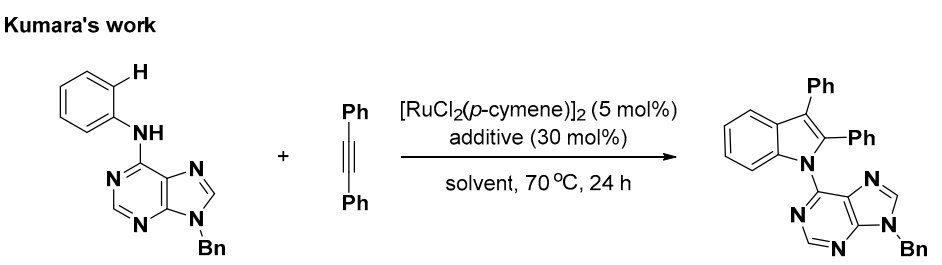

Scheme 4. Ru-catalyzed C-H activation with alkynes and anilines to afford indoles derivatives. 
In 2019, the first ruthenium-catalyzed double aryl C( $\left(\mathrm{sp}^{2}\right)-\mathrm{H}$ bond activation of antipyrine and alkyne annulation reaction was reported by Sanjib Gogoi [17] and his co-workers. Two equivalents of anilines participated in the reaction to afford indolo [2,1-a]isoquinolines (Scheme 5). The possible mechanism was proposed (Scheme 6). First of all, ruthenium catalyst conducted irreversible $\mathrm{C}\left(\mathrm{sp}^{2}\right)-\mathrm{H}$ activation with the directing group assisted. Subsequently, ruthenium-alkyne coordination occurs, followed by migratory alkyne insertion into Ru-C bond. Then, the weak $\mathrm{N}-\mathrm{N}$ bond cleavages with the oxidation of $\mathrm{Ru}(\mathrm{II})$ to $\mathrm{Ru}(\mathrm{IV})$ to provide a six-membered $\mathrm{Ru}(\mathrm{IV})$ complex. Next, before further $\mathrm{C}\left(\mathrm{sp}^{2}\right)-\mathrm{H}$ activation of the substituted phenyl ring, the Ru metal is reductive eliminated, and a nine-membered $\mathrm{Ru}$ complex is formed. After that, the nine-membered ring is contracted by elimination of a ketene type of fragment to generate $\mathrm{Ru}(\mathrm{IV})$ complex. Again, 3aa is afforded with the insertion of another molecular of $\mathbf{2 a}$ into the $\mathrm{Ru}-\mathrm{C}$ bond and reductive elimination of $\mathrm{Ru}$.

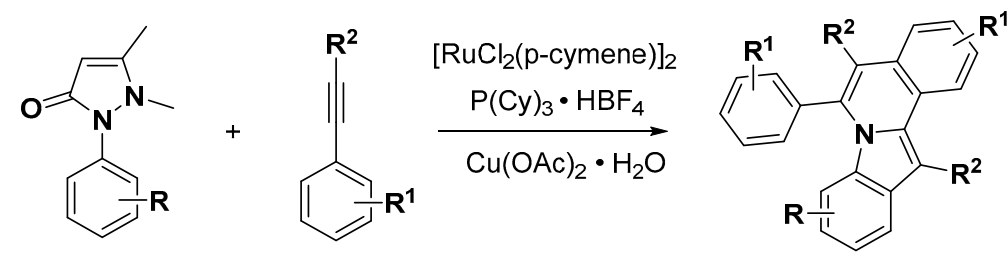

\footnotetext{
$\mathrm{R}=$ alkyl, halogen, $\mathrm{CF}_{3}$, $\mathrm{MeO}$

$\mathrm{R}^{1}=\mathrm{MeO}$, alkyl, $\mathrm{F}$ $\mathrm{R}^{2}=\mathrm{MeOPh}, \mathrm{FPh} .$.
}

$55 \%-77 \%$ yields

Scheme 5. Ruthenium(II)-catalyzed oxidative double $\mathrm{C}-\mathrm{H}$ activation and annulation to afford indolo $[2,1-a]$ isoquinolines.

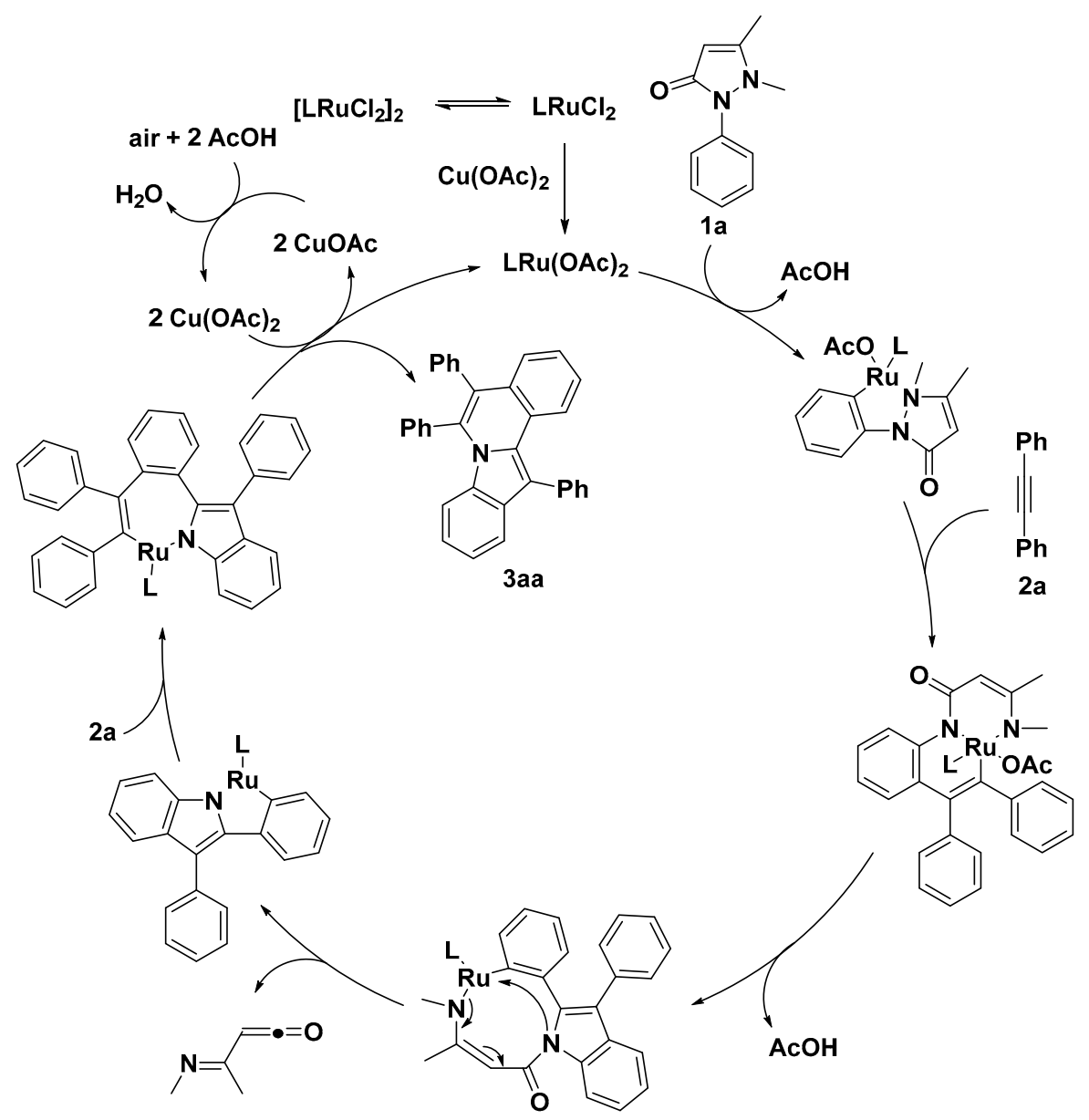

Scheme 6. Proposed reaction mechanism. 
Inspired by the $\mathrm{C}-\mathrm{H}$ activations directed by the groups on benzenes, Chen [18] and his coworkers developed Ruthenium(II)-catalyzed [3+2] annulation of $N$-nitrosoanilines with alkynes for the synthesis of indole derivatives (Scheme 7). This ruthenium(II)-catalyzed $\mathrm{C}-\mathrm{H}$ bond redox-neutral [3+2] cycloaddition features a broad range of functional group tolerance and excellent sterically controlled regioselectivity.

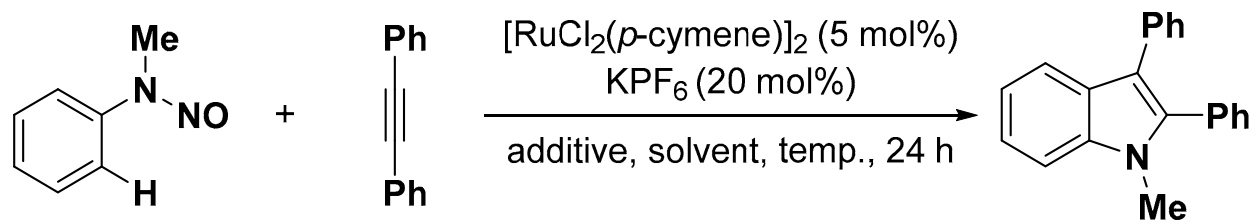

Scheme 7. Ruthenium(II)-catalyzed $\mathrm{C}-\mathrm{H}$ bond [3+2] annulation of $\mathrm{N}$-nitrosoanilines with alkynes in water.

Emma Gallo [19] and his coworkers screened out ruthenium bis-imido $\mathrm{Ru}(\mathrm{TPP})(\mathrm{NAr})_{2}$ complex $\left(\mathrm{TPP}=\right.$ dianion of tetraphenyl porphyrin, $\left.\mathrm{Ar}=3,5-\left(\mathrm{CF}_{3}\right)_{2} \mathrm{C}_{6} \mathrm{H}_{3}\right)$, also named ruthenium porphorin, to catalyze indole synthesis from alkynes with aryl azide (Scheme 8). The alkyne interacts with one NAr imido ligand of $\mathrm{Ru}(\mathrm{TPP})(\mathrm{NAr}) 2$ to form a residually dangling $\mathrm{C}(\mathrm{Ph})$ group, forming a $5+6$ bicyclic molecule by coupling with a $\mathrm{C}(\mathrm{H})$ unit of the N-aryl substituent, a two-step outer sphere H-migration occurs to make the bicycle isomerize to indole. Eventually, a Ru(TPP)(NAr) mono-imido active catalyst is reformed after each azide/alkyne reaction. The steric hindrance of alkynes influenced the reaction productivity to a greater extent than the electronic effect, as the mono-substituted alkynes were efficiently converted into corresponding indole independently for the position where the substituent was placed, while the substitution on the phenyl azide shows lower selectivity.

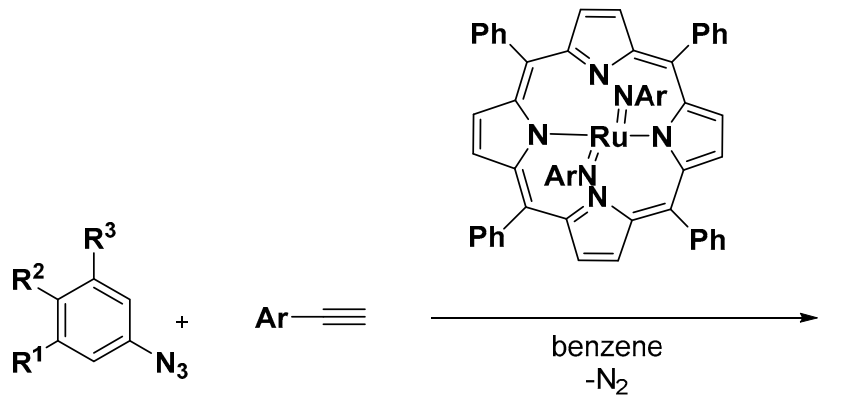

$\mathrm{R}^{1}=\mathrm{H}, \mathrm{CF}_{3}, \mathrm{NO}_{2}$, halogen...

$\mathrm{R}^{2}=\mathrm{H}, \mathrm{Me}$

$\mathrm{R}^{3}=\mathrm{H}, \mathrm{CF}_{3}, \mathrm{NO}_{2}$, halogen...

$\mathrm{Ar}=\mathrm{CF}_{3} \mathrm{Ph}, \mathrm{FPh}, \mathrm{MePh}, \mathrm{MeOPh}, \mathrm{CHOPh}, \mathrm{MeO}_{2} \mathrm{CPh} \ldots$<smiles>[R]c1cc2[nH]cc([Al])c2c([R])c1[R]</smiles>

$30 \%-90 \%$ yields

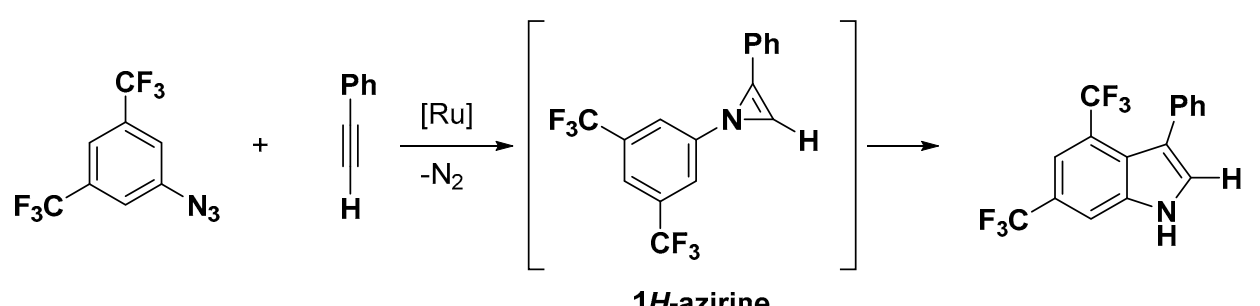

Scheme 8. Ruthenium porphyrin-catalyzed $\mathrm{C}-\mathrm{H}$ activation with alkynes and aryl azides to afford indoles. 
In the methods above, most of the catalytic cycle needs additional oxidant to reform the catalyst such as $\mathrm{Cu}$ salt. Xu's group [20] developed a ruthenium-catalyzed electrochemical dehydrogenative annulation reaction of aniline derivatives and alkynes (Scheme 9). Electric current is used to recycle the active ruthenium-based catalyst, and the reaction, notably, is operationally convenient due to a simple undivided cell employed. The process is insensitive to air, proceeding in an aqueous solution.

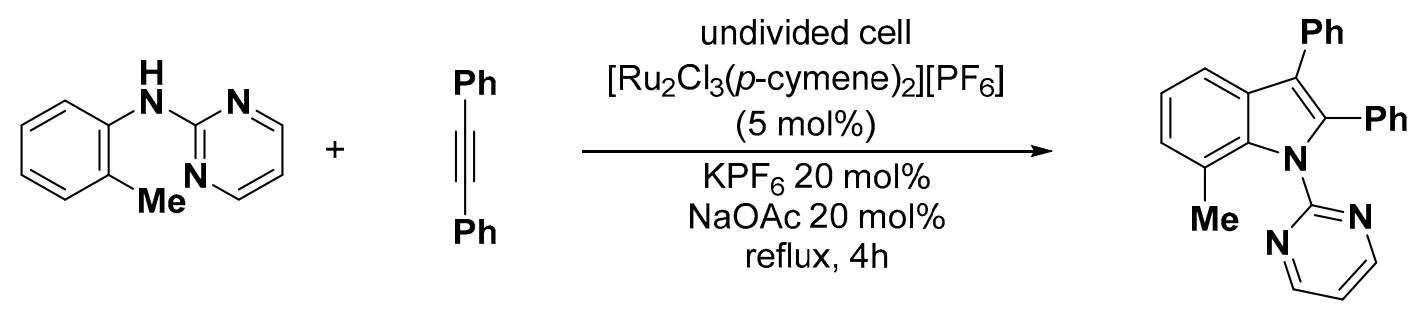

Scheme 9. Ruthenium-catalyzed electrochemical dehydrogenative alkyne annulation.

Similarly, alkenyl groups can also be applied to form indole derivatives with $\mathrm{C}-\mathrm{H}$ activation reactions. Xiao [21] and his coworkers developed a visible light-induced intramolecular cyclization of styryl azide in the presence of $\mathrm{Ru}(\mathrm{bpy})_{3} \mathrm{Cl}_{2}$, to construct 2-substituted $\mathrm{N}$-free indoles in good to excellent yields with high functional group tolerance. Through this method, 2 aromatic indoles including electron-donating phenyl and electron-withdrawing phenyl indoles are efficiently obtained. (Scheme 10). A molecular of $\mathrm{N}_{2}$ is removed under irradiation of visible light, and then a concerted nitrene insertion occurs through the transition state to deliver the designed indoles.<smiles></smiles>

$\mathrm{Ar}=\mathrm{MePh}, t$-BuPh, NCPh, $\mathrm{CF}_{3} \mathrm{Ph}, \mathrm{NO}_{2} \mathrm{Ph} \ldots$<smiles>[Mg]Cc1cc2ccccc2[nH]1</smiles>

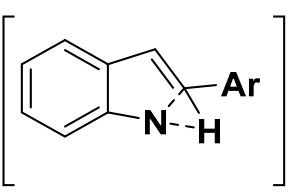

Transition state

Scheme 10. Ruthenium-catalyzed cyclizations of styryl azides induced by visible light.

Yang's group [22] developed a new approach to the synthesis of 2-phosphinoylindoles from 1-isocyano-2-styrylbenzenes through photoredox catalysis (Scheme 11). Unlike Xiao's work, the benzyl group on the alkenylphenylisocyanide is ultimately substituted on the C3 of the synthesized indole. The proposed mechanism of the phosphorylation/ cyclization reaction was outlined by the author (Scheme 12). The photoredox catalyst $\mathrm{A} \mathrm{Ru}(\mathrm{bpy})_{3} \mathrm{Cl}_{2} \cdot 6 \mathrm{H}_{2} \mathrm{O}$ irradiated by visible light, leading to the formation of excited state $\mathbf{B}{ }^{*} \mathrm{Ru}^{\mathrm{II}}$. After that, oxidation of the conjugate base of $\mathbf{B}$ should be thermodynamically feasible, to generate phosphorus radical $\mathbf{D}$. Then, a proton from diphenylphosphine oxide 2 is captured by DBU. After that, phosphorus radical $\mathbf{D}$ is rapidly trapped by 1-isocyano-2-styrylbenzene (1a) to generate alkene radical E, followed by 5-exo-trig cyclization-forming benzyl radical $\mathbf{F}$. Finally, the reduction in the resulting benzyl radical $\mathbf{F}$ by SET from available Ru species $\mathbf{C}$ should generate benzyl anion $\mathbf{G}$ and regenerate the ground-state photoredox catalyst $\mathbf{A}$. A range of 1-isocyano-2-styrylbenzenes can be applied efficiently in this transformation, making it appealing for late-stage synthesis strategies. 
<smiles>[R17]C=Cc1c[Z17]ccc1N=[W]</smiles>

NC<smiles>[C+]1CCCC1</smiles><smiles>[R][PH]([R])=O</smiles><smiles></smiles>

$\mathrm{BU}$ (2.0 equiv.) $\mathrm{CH}_{3} \mathrm{CN} / \mathrm{H}_{2} \mathrm{O}(1.0 / 0.14 \mathrm{~mL})$

$$
\mathrm{Ar}, 25^{\circ} \mathrm{C}
$$

$\mathrm{R}=\mathrm{H}, \mathrm{Me}, \mathrm{MeO}$

$\mathrm{Ar}=\mathrm{Ph}$, thiophene, pyridine, $\mathrm{MeOPh}, \mathrm{FPh}, \mathrm{CF}_{3} \mathrm{Ph} \ldots$

$\mathrm{R} 1=\mathrm{Ph}, \mathrm{Et}, \mathrm{MePh}, \mathrm{MeOPh}$<smiles>[R][R]([R])(=O)c1[nH]c2cc[R]#cc2c1C[Al]</smiles>

up to $90 \%$ yields $\mathrm{R} 2=\mathrm{Ph}, \mathrm{Et}, \mathrm{MePh}, \mathrm{MeOPh}, n-\mathrm{Bu} .$.

Scheme 11. Ruthenium-catalyzed photoredox reactions to afford 2-phosphinoylindoles.

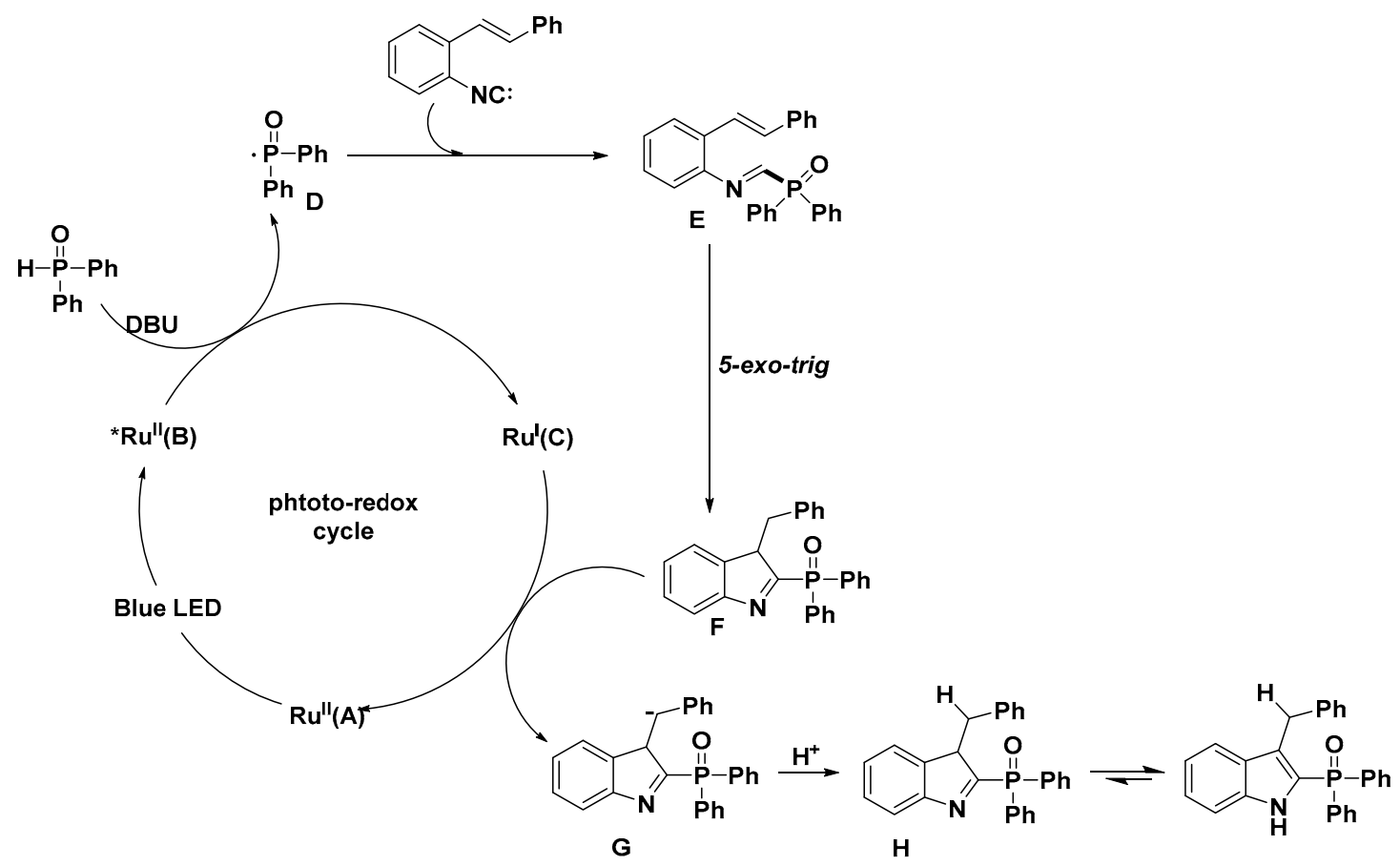

Scheme 12. Proposed reaction mechanism.

Sulfur ylides also serve as significant substrates forming indole derivatives in ruthenium-catalyzed reactions. Our lab [23] developed the first sulfoxonium ylides derived from a $\mathrm{Ru}$ (II)-carbene complex insertion arene $\mathrm{C}-\mathrm{H}$ bond cascade reactions to constitute 3-ketoindole skeleton via $\mathrm{C}-\mathrm{H}$ activation. The catalytic system generated 3-acetyl indole scaffolds by C-N and C-S bond cleavage with imidamides and sulfoxonium ylides through a [4+1] cyclization process. In addition, Huang and his coworkers developed a method for the synthesis of 2-arylindoles with $N$-aryl-2-aminopyridines and $\alpha$-carbonyl sulfoxonium ylides (Scheme 13). Some 2-aromatic-substituted indoles including halogenatedphenyl, trifluoromethylphenyl, and methoxylphenyl indoles are obtained in good yields. 
<smiles>[R]C(=N)Nc1cc#[R1]cc1</smiles><smiles>[R][C+](C)[SH](C)(C)=CC(=O)O</smiles>

$\mathrm{R}^{1}=\mathrm{H}$, halogen, alkyl, $\mathrm{MeO}, \mathrm{CN} .$. $\mathrm{R}^{2}=\mathrm{Ph}, \mathrm{CF}_{3}, \mathrm{NMe}_{2}, \mathrm{Bn} \ldots$ $\mathrm{R}^{3}=$ halogen, $\mathrm{CF}_{3}, \mathrm{Ph}$, cyclopropyl, cyclohexyl...
$\left[\operatorname{RuCl}_{2}(p \text {-cymene })\right]_{2}(5 \mathrm{~mol} \%)$<smiles>[Y]OC(=O)c1c([R])[nH]c2c1C=C[R1]C=C2</smiles>

$61 \%-88 \%$ yields

Scheme 13. Ruthenium-catalyzed indole scaffold construction with sulfur ylides.

In 2017, Dilman's group [24] developed a method for the synthesis of 3-fluoroindoles starting from $-\mathrm{CF}_{2} \mathrm{I}$-substituted $\mathrm{N}$-arylamines, which was mediated by a ruthenium photocatalyst upon irradiation with blue light in the presence of a substoichiometric amount of triphenylphosphine (Scheme 14). The combination of ruthenium photocatalyst and triphenylphosphine to generate fluoroalkyl radicals is the key factor affecting the reaction efficiency.<smiles>[R]c1ccc(N([R])C([R])C(F)(F)I)cc1</smiles>

$\mathrm{R} 1=\mathrm{Ph}, \mathrm{MePh}, \mathrm{MeOPh}, i-\mathrm{Pr}$... $\mathrm{R} 2=$ alkyl... R3= halogen, MeO...

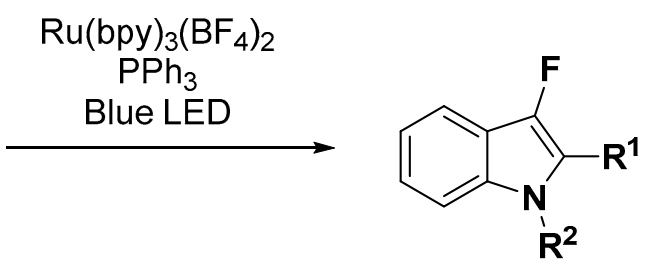

$80 \%-98 \%$ yields

Scheme 14. Ruthenium-catalyzed fluorine-containing indoles induced by visible light.

There are also additional methods using variety of substrates. According to Shim's report [25], substituted indoles can be synthesized from anilines and alkanolammonium chlorides in the presence of a ruthenium catalyst together with $\mathrm{SnCl}_{2} \cdot 2 \mathrm{H}_{2} \mathrm{O}$ in moderate to good yields. In this transformation, $\mathrm{SnCl}_{2} \cdot 2 \mathrm{H}_{2} \mathrm{O}$ is important for the formation of indoles. Karvembu [26] utilizes $\left[\mathrm{RuCl}_{2} \text { (p-cymene) }\right]_{2}$ complexes containing picolyl-based pseudo-acylthiourea ligands to form 3-isopropoxy-1H-indole from nitro 2-nitrocinnamaldehyde and 2-propanol. Jana [27] and his coworkers developed a ruthenium-catalyzed divergent synthesis of 2-methylindoles and indolines via a $\mathrm{C}-\mathrm{H}$ allylation/oxidative cyclization cascade. The 2-methylindoles are obtained through a $\mathrm{C}-\mathrm{H}$ allylation/carboamination/ $\beta$-hydride elimination/double bond isomerization cascade, whereas for ortho-substituted anilines, the indolines are obtained via a $\mathrm{C}-\mathrm{H}$ allylation/carboamination/protodemetalation cascade in trifluoroethanol. Yi [28] and his coworkers reported a dehydrative $\mathrm{C}-\mathrm{H}$ coupling reaction of arylamines with 1,2-diols catalyzed by the cationic ruthenium-hydride complex to afford 2-phenyl indoles (Scheme 15). 


\section{Shim's work}<smiles>[R]c1ccc(N)cc1</smiles>

$\mathrm{R}=\mathrm{Me}, \mathrm{OMe}, \mathrm{Cl}, i-\mathrm{Bu}$

up to $99 \%$ yields totally

\section{Karvembu's work}<smiles>O=C/C=C/c1ccccc1[N+](=O)[O-]</smiles>

$\underset{\mathrm{KOH}(0.5 \mathrm{mmol})}{\stackrel{\text { cat. } \mathrm{Ru}(0.1 \mathrm{~mol} \%)}{\longrightarrow}}$

2-propanol (4 mL)

$82{ }^{\circ} \mathrm{C}, 18 \mathrm{~h}$<smiles>CC(C)Oc1c[nH]c2ccccc12</smiles>

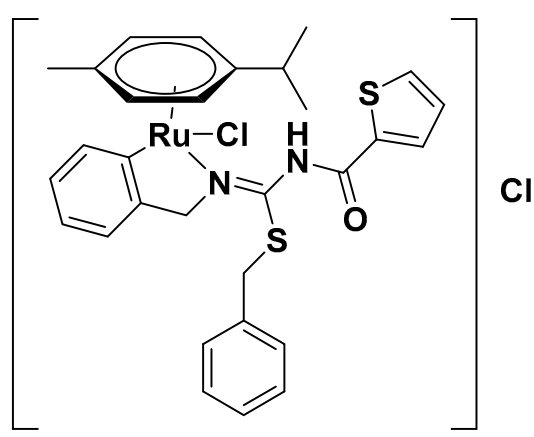

\section{Jana's work}

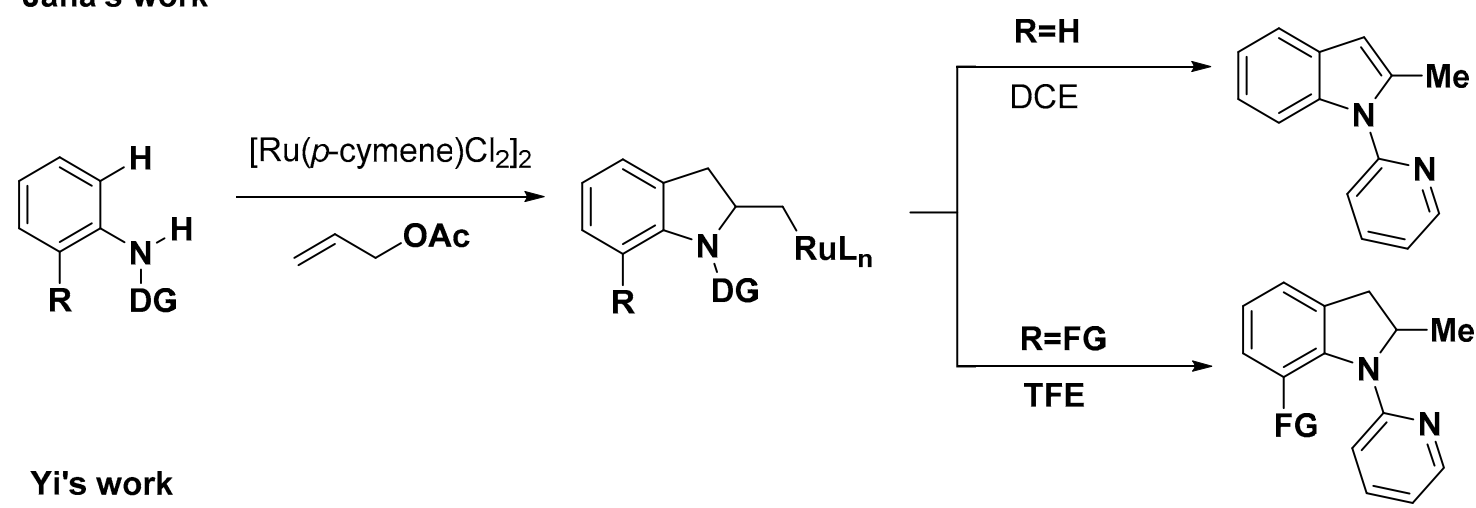

Yi's work

$\left[\mathrm{RuH}(\mathrm{CO})\left(\mathrm{PCy}_{3}\right)\right]_{4}(\mathrm{O})(\mathrm{OH})_{2}$ $(0.75 \mathrm{~mol} \%)$<smiles>Nc1c[R]ccc1</smiles>

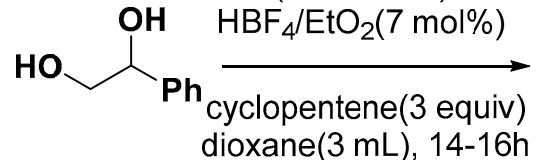<smiles>c1ccc(-c2cc3ccccc3[nH]2)cc1</smiles>

$\mathrm{R}=\mathrm{H}, \mathrm{MeO}$.

$42 \%-94 \%$ yields

Scheme 15. Ruthenium-catalyzed indole scaffold construction with other substrates.

\section{Site-Specific Modification for Indole Scaffold via Ruthenium-Catalyzed C-H Activation}

Site-specific direct $\mathrm{C}-\mathrm{H}$ functionization is a simple and significant way to obtain desired indole derivatives [29]. In order to discuss conveniently, these $\mathrm{C}-\mathrm{H}$ activation strategies will be sorted according to the site of $\mathrm{C}-\mathrm{H}$ bond on indoles. 


\section{1. $\mathrm{C}-\mathrm{H}$ Activation on $\mathrm{C} 2$ and $\mathrm{C} 3$}

Cross coupling is gradually becoming the most significant and one of the most applied reactions in the pharmaceutical industry. A significant number of methods exist for Ru-catalyzed functionalization at the C2 position of indole scaffolds, such as alkylation, arylation, and so on. In 2011, Ackermann [30] and his coworkers reported $\mathrm{C}-\mathrm{H}$ bond arylations in a high chemo- and site-selective manner using the removable directing group with aryl halides as coupling partners. The catalytic system is reported broadly applicable and tolerated a variety of valuable functional groups, such as halogen, cyano, and carbonyl group, as well as additional heteroaromatic moieties in medium-to-good yields. Based on Ackermann's work, in 2015 and 2018, Pilarski [31] and Szostak [32] reported the similar C-H arylation reactions for the synthesis of 2-arylated indoles with aryl borate and aryl silicone compounds, respectively (Scheme 16).

\section{Ackermann's work}<smiles></smiles>

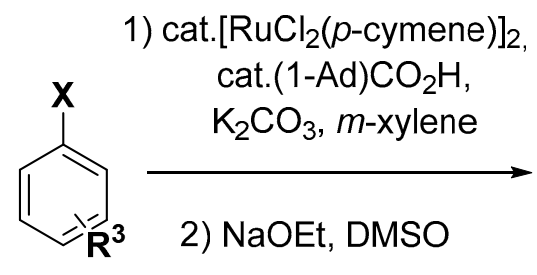<smiles>[R]c1c(-c2ccccc2)[nH]c2cc[R1]cc12</smiles>

$\mathrm{X}=\mathrm{Br}, \mathrm{Cl}$

$\mathrm{R}^{1}=\mathrm{H}, \mathrm{MeO}$, etc.

$\mathrm{R}^{2}=\mathrm{H}$, alkyl, etc.

$\mathrm{R}^{3}=$ halogen, $\mathrm{CN}, \mathrm{CO}_{2} \mathrm{Et}, \mathrm{NMe}_{2}$, etc.

\section{Pilarski's work}

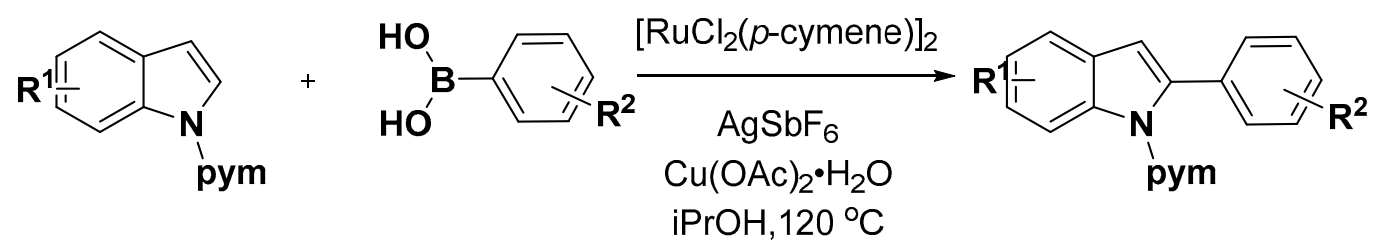

$\mathrm{R}^{1}=$ halogen, $\mathrm{Me}, \mathrm{MeO}, \mathrm{COOMe}$, etc.

$\mathrm{R}^{2}=$ alkyl, alkoxy, halogen, $\mathrm{NO}_{2}$, etc.

\section{Szostak's work}<smiles>[H][R]n1c([TlH])cc2cc[R1]cc21</smiles>

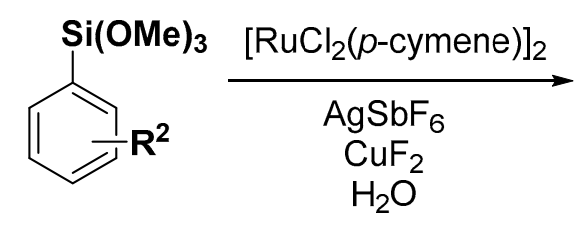

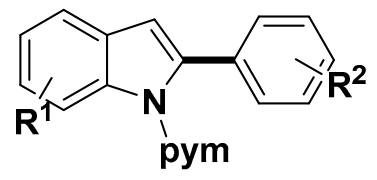

$\mathrm{R}^{1}=\mathrm{COOMe}, \mathrm{Me}, \mathrm{NO}_{2}, \mathrm{MeO}$, etc.

$\mathrm{R}^{2}=\mathrm{Me}$, halogen, $\mathrm{CF}_{3}$, MeO, etc.

Scheme 16. Ruthenium-catalyzed $\mathrm{C}-\mathrm{H}$ arylation on $\mathrm{C} 2$ of indoles. 
In 2016, Ackermann [33] reported a methylation reaction using $\mathrm{MeBF}_{3} \mathrm{~K}$ as methylating agent, with the catalysis of $\left[\mathrm{RuCl}_{2}(p \text {-cymene) }]_{2}\right.$ (Scheme 17). Notably, the reaction can be applied in the methylation of tryptophan, which may be used in the chemical biology field or pharmaceutical industry.<smiles>[R]c1c([2H])n([R20])c2cc[R1]cc12</smiles>

$\mathrm{R}^{1}=\mathrm{Me}, \mathrm{OMe}$, halogen, $\mathrm{NO}_{2}$

$\mathrm{R}^{2}=\mathrm{Me}, \mathrm{CO}_{2} \mathrm{Me}, \mathrm{C}(\mathrm{O}) \mathrm{Me}, \mathrm{CHO} \ldots$

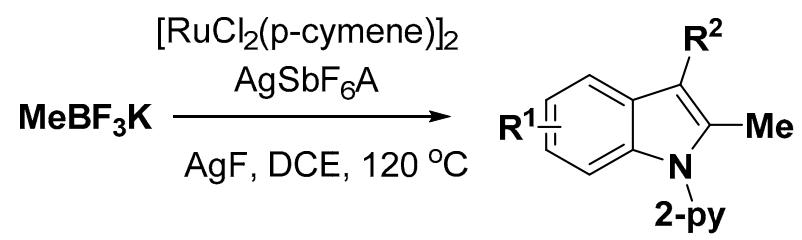

$60 \%-93 \%$ yields

Scheme 17. Ruthenium-catalyzed C-H methylation on $\mathrm{C} 2$ of indoles.

Diazo compounds are critical and reactive substrates to participate all sorts of insertion reactions by forming metal carbenes. In 2010, Yu reported a directing group-free approach for $\mathrm{C} 2$-selective carbenoid functionalization of $\mathrm{NH}$ indoles [34]. With $\left[\mathrm{RuCl}_{2} \text { (p-cymene) }\right]_{2}$ as catalyst and 2-aryldiazoesters as carbenoid source, 2-alkylated indoles were obtained in up to $96 \%$ isolated yield. In 2019, Gryco [35] described the photoalkylation of indoles and pyrroles with diazo esters. C2- alkylated indoles are obtained with good yields even though the photocatalyst loading is as low as $0.075 \mathrm{~mol} \%$ (Scheme 18). Both EWG (electron donating groups)-EWG- and EWG-EDG (electron withdrawing groups)-substituted diazo esters are suitable as alkylating agents in this transformation. For EWG-substituted substrates, the addition of a catalytic amount of $\mathrm{N}, \mathrm{N}$-dimethyl-4-methoxyaniline is required to promote the transfer from the $\mathrm{Ru}(\mathrm{bpy})_{3}{ }^{* 2+}$ to $\mathrm{Ru}(\mathrm{bpy})_{3}{ }^{+}$, which has much more potential to catalyze the reaction.

\section{Yu's work}<smiles>[R]c1c([NH+])[nH]c2c([R])cccc12</smiles><smiles></smiles><smiles>CCOCCOCCOCCOCCO</smiles>

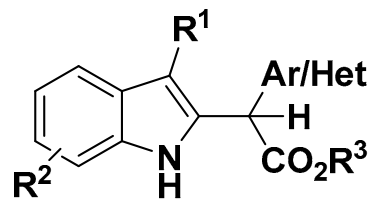

$$
\begin{aligned}
& R^{1}=H, M e \\
& R^{2}=\text { halogens, ether } \\
& R^{3}=M e, \text { Allyl group }
\end{aligned}
$$

\section{Gryco' work}<smiles>[R]n1c([1H])cc2c[R]#ccc21</smiles><smiles>[R]OC(=[R])C([R])=[W]</smiles>

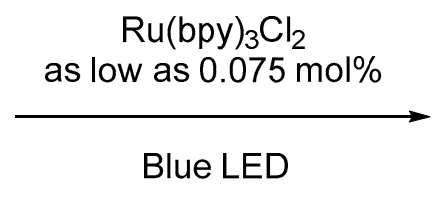<smiles>[R1]OC(=O)C([R])c1cc2[R4]([R])cccc2n1[R]</smiles>

Scheme 18. Visible-light-induced C-H activation catalyzed by ruthenium with diazo compounds.

The same situation appears in Stephenson's work [36]. Substituted indoles were obtained by photoredox intermolecular direct $\mathrm{C}-\mathrm{H}$ functionization with indoles and diethyl bromomalonate. The replacement of $\mathrm{Et}_{3} \mathrm{~N}$ with $\mathrm{N}$, $\mathrm{N}$-dimethyl-4-methoxyaniline increased the yield of desired product 
from $25 \%$ to $85 \%$. Meanwhile, furans and pyrroles were also investigated and found to work well under the conditions. In 2017, Hansen reported a similar method and developed a novel visible-light photocatalytic double $\mathrm{C}-\mathrm{H}$ functionalization of indoles to afford 2,3-difunctionalized indoles (Scheme 19). Mechanistic studies indicated that electrophilic C-3 bromination occurs through an independent photocatalytic oxidation of bromide ions formed during the reaction to generate molecular bromine [37].

Stephensen's work
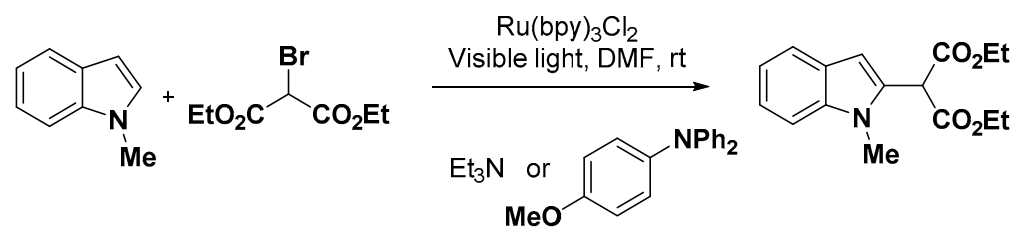

Hansen's work

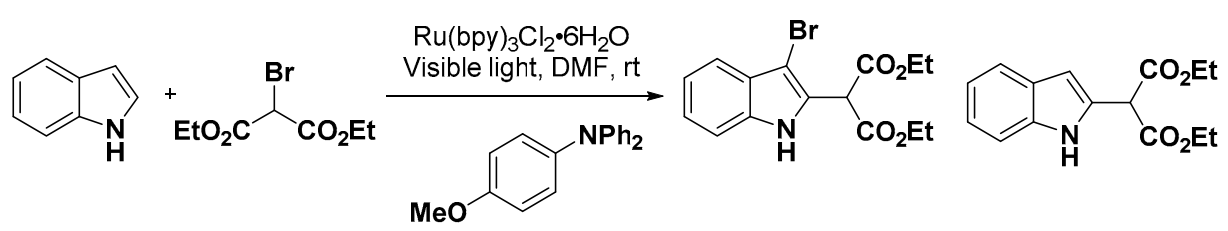

Scheme 19. Visible-light-induced C-H activation catalyzed by ruthenium with diethyl bromomalonate.

In the field of drug research and development, metabolism of drugs leading to low bioavailability or toxicity is a huge challenge to be solved [38]. Trifluoromethylation on the active metabolic site gives medicinal chemists new hope to guarantee the efficacy of drugs [39]. It is clearly important to develop easy methods to realize trifluoromethylation reaction under mild conditions with simple starting materials. In 2011, MacMillan [40] introduced a photoredox-based method allowing for facile trifluoromethylation of heteroaromatic systems including indoles without the need for an aryl ring pre-activation (Scheme 20). With the $\mathrm{Ru}\left(\right.$ phen) ${ }_{3}{ }^{2+}$ as photoredox catalyst, as well as trifluorosulfonyl chloride as $\mathrm{CF}_{3}$ source, 2- $\mathrm{CF}_{3}$-indole and 3- $\mathrm{CF}_{3}-\mathrm{N}$-Ac-indole were afforded in this catalytic system, respectively. In addition, on all kinds of hetero- or benzene cycles, the substitutions majorly rely on the electro property. In 2012, Cho [41] reported the similar trifluoromethylation of indole substrates utilizing $\mathrm{CF}_{3} \mathrm{I}$ as $\mathrm{CF}_{3}$ source. The trifluoromethylation reaction can occur on substituted indoles. Then, in 2014, continuous flow was used to accelerate the trifluoromethylation and multifluoroalkylation process, shortening the time from tens of hours to dozens of minutes [42].

Growing interest in the utility of arylsilanes or heteroarylsilanes in synthesis [43] and medicinal chemistry has fueled the development of powerful C-H silylation methods. Tatsumi [44] and his group developed selective Ru-catalyzed C3-H silylation of N-methyl indoles (Scheme 21). Either with or without the assistance of the directing group, the transformation proceeds well. The $\mathrm{C}-\mathrm{H}$ activation occurs as a manner of merging cooperative $\mathrm{Si}-\mathrm{H}$ bond activation and electrophilic aromatic substitution, which make the C3 selective functionalization controlled by electronic factors (Scheme 22). $\mathrm{Ru}$ cooperates with $\mathrm{S}$ to form an unsaturated cationic complex before splitting the $\mathrm{Si}-\mathrm{H}$ bond, which gives a sulfur-stabilized silicon electrophile. The sulfur atom then participates the deprotonation of the Wheland intermediate of the Friedel-Crafts-type process. Solvent does not participate the overall catalysis, with only dihydrogen liberated. 


\section{Macmillan's work}

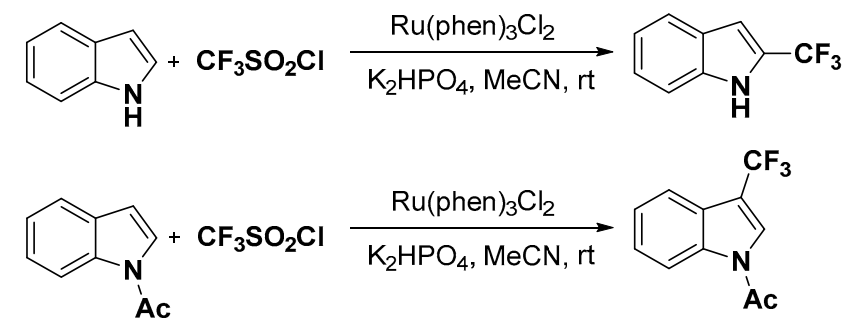

Cho's work

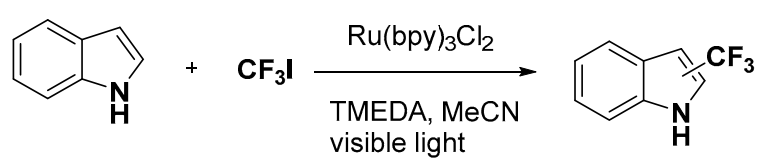

Scheme 20. Visible-light-induced trifluoromethylation on indoles catalyzed by ruthenium.

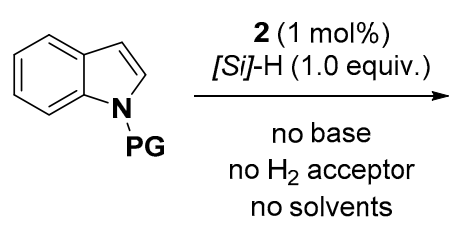

no solvents

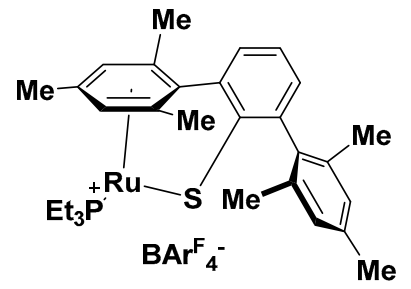

2

Scheme 21. Ruthenium-catalyzed C2-H siliconization on indoles.

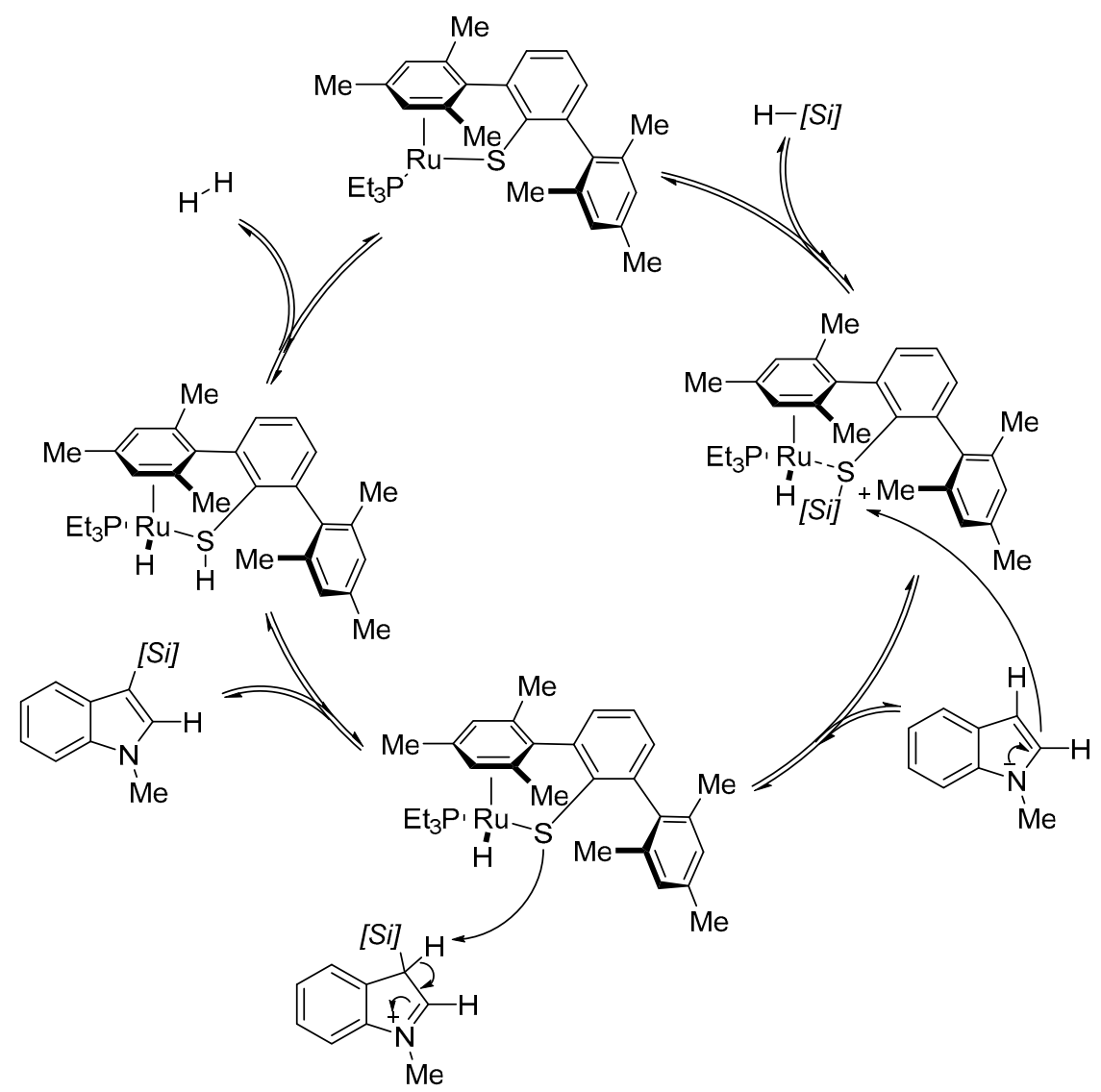

Scheme 22. Proposed reaction mechanism. 
Pilarski [45] and his coworkers utilize $\left[\mathrm{RuH}_{2}(\mathrm{CO})\left(\mathrm{PPh}_{3}\right)_{3}\right]$ as catalyst to conduct direct $\mathrm{C}-\mathrm{H}$ sililation at $\mathrm{C} 2$ position of $\mathrm{NH}$ indoles (Scheme 23). Gramines and tryptamines can be converted efficiently, although the $\mathrm{C}-\mathrm{H}$ activation on $\mathrm{C}-4$ site was detected when conducting mechanism research with little side reactions. Good-to-excellent yields of designed products were effectively obtained from a different silane source such as triaryl, trialkyl, and mixed alkyl/aryl silanes.

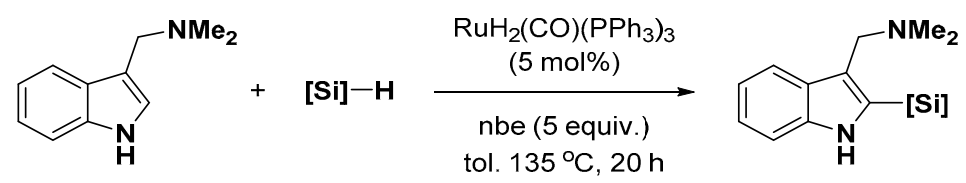

Scheme 23. Ruthenium-catalyzed C2-H siliconization on indoles.

Alkynes also serve as a vital sort of substrates for C-H activation. In 2010, Gimeno [46] and his coworkers reported a ruthenium/trifluoroacetate-catalyzed regioselective C-3-alkylation reaction of indoles with terminal alkynes, affording a branch alkyl chain on the scaffold (Scheme 24).

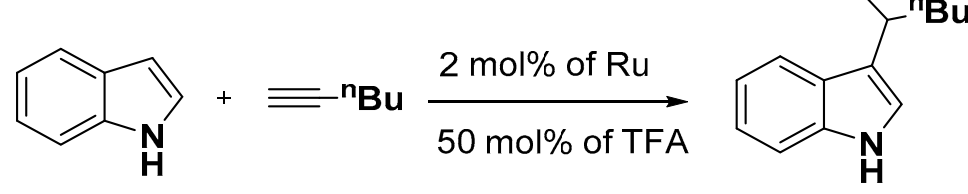

$$
\mathrm{Ru}=\left[\left\{\mathrm{RuCl}(\mu-\mathrm{Cl})\left(\eta^{6}-1,3,5-\mathrm{C}_{6} \mathrm{H}_{3} \mathrm{Me}_{3}\right)\right\}_{2}\right]
$$

Scheme 24. Ruthenium-catalyzed alkylation on C3 of indoles.

In 2016, Dixneuf's group [47] developed an indole-fused isocoumarins synthetic method from 1-methylindole-3-carboxylic acid by annulation with alkynes under $\left[\mathrm{RuCl}_{2}(p \text {-cymene) }]_{2}\right.$ catalyst (Scheme 25). It shows that this catalytic annulation performs well in water, with medium-to-good yields and regio-selectivity, with dialkylalkynes, diarylalkynes, or mixed alkynes as substrates.

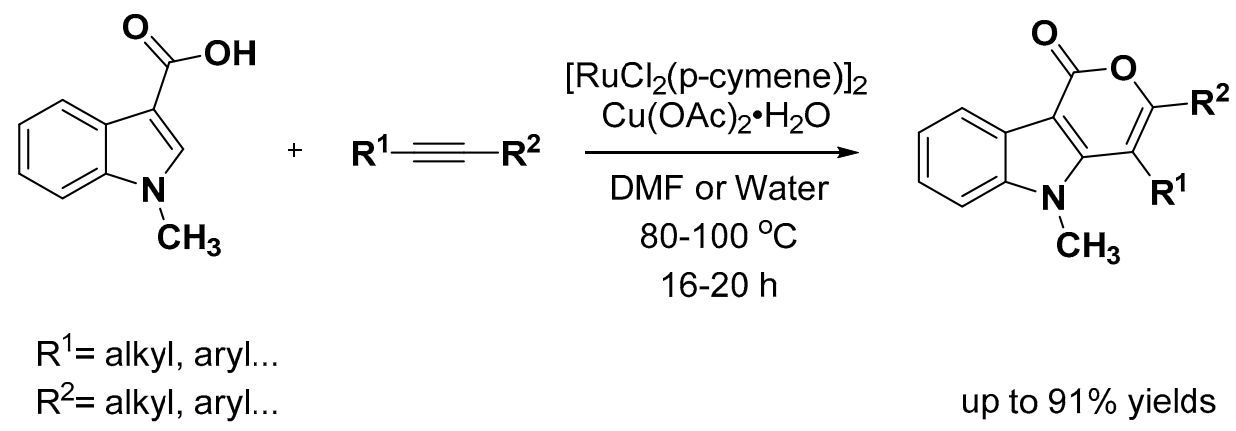

Scheme 25. Ruthenium-catalyzed C2-H activation of indoles with alkynes.

Our lab [48] reported $\mathrm{Ru}(\mathrm{II})$-catalyzed redox-neutral [3+2] annulation reactions on $\mathrm{N}$-ethoxycarbamoyl indoles with substituted alkynes (Scheme 26). Many sorts of internal alkyne show good-to-excellent regio-selectivities and mild reaction conditions, and various aryl/alkyl-, alkyl/alkyl, and diaryl-substituted alkynes are included. 
<smiles></smiles>

$\mathrm{R}^{1}=$ aryl, alkyl

$\mathrm{R}^{2}=$ aryl, alkyl

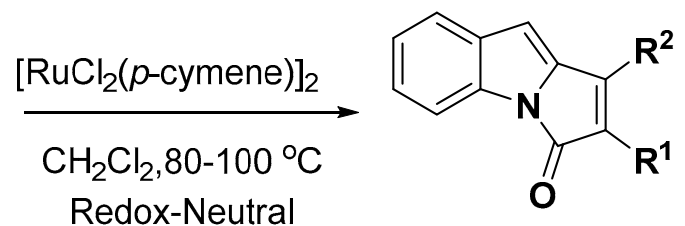

up to $96 \%$ yields

Scheme 26. Ruthenium-catalyzed $\mathrm{C} 2-\mathrm{H}$ activation of indoles with alkynes to afford Pyrroloindolone Scaffold.

In 2012, Haak [49] and his coworkers introduced a ruthenium-catalyzed functionalization of indoles and pyrroles with propargyl alcohols utilizing ruthenium complex 1Ba (Scheme 27). Notably, this protocol can be used for the construction of multi-substituted indole scaffolds with the cascade cyclization on pyrroles. In 2018, they also developed a cascade annulation reaction with propargyl alcohols catalyzed by ruthenium to give benzene-fused indoles [50].

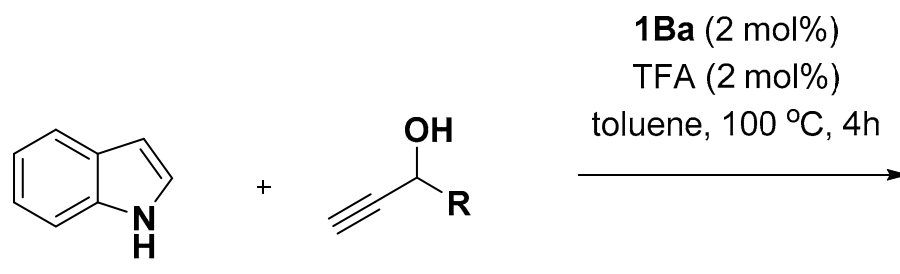

$\mathrm{R}=\mathrm{Me}, \mathrm{Ph}$, alkenyl...<smiles>[R]C(=O)Cc1c[nH]c2ccccc12</smiles>

up to $91 \%$ yields

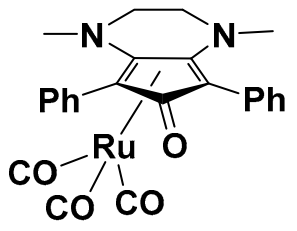

$1 \mathrm{Ba}$

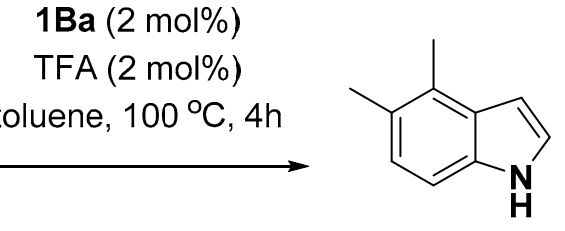

Scheme 27. Ruthenium-catalyzed C-H activation to afford substituted indoles with alkynol.

Similarly, olefins are widely used in indole substitution to perform vinylation or alkylation reactions. In 2013, Wang's lab [51] and Song's lab [52], respectively, developed a similar efficient protocol for vinylation selectively on $\mathrm{C} 2$ of indoles assisted by the employment of $\mathrm{N}, \mathrm{N}$-dimethylcarbamoyl moiety as a directing group (Scheme 28). A wide scope of olefins, including electron-donating groups, such as the phenyl group, and electron-withdrawing groups, such as sulfonyl, phosphate, and cyano groups, are applicable in this reaction.

Among the substituted alkenes, $\alpha, \beta$-unsaturated esters are well studied. Prabhu [53] and his coworkers developed a novel versatile regioselective C-2 alkenylation strategy catalyzed by ruthenium for the synthesis of indole derivatives with benzoyl group as a directing group (Scheme 29). A variety of esters such as methyl, ethyl, cyclohexyl, and phenyl esters perform in good yield. Notably, hydrolysis happens on tert-butyl ester after the designed reaction. Similar conclusions can be found in $\mathrm{Wu}^{\prime} \mathrm{s}$ work [54].

In 2018, Liu [55] reported a traceless directing group assisted by $\mathrm{C} 2-\mathrm{H}$ vinylation reaction on indoles with broad substrate scope in an aqueous solution (Scheme 30). Decarboxylation occurs after intramolecular alkenylation affording tetrahydropyridoindoles. This method provides efficient access to synthesize various indole-fused derivatives under mild conditions. 
<smiles>CN(C)C(=O)n1ccc2ccccc21</smiles><smiles>[R]C=C([R])[R]</smiles>

$\mathrm{SO}_{2} \mathrm{Ph}$<smiles>CN(C)C(=O)n1c(/C=C/S(=O)(=O)c2ccccc2)cc2ccccc21</smiles>

3an, $87 \%$

$\left[\mathrm{RuCl}_{2} \text { (p-cymene) }\right]_{2} 2.5 \mathrm{~mol} \%$ $\mathrm{AgSbF}_{6} 10.0 \mathrm{~mol} \%$

$\mathrm{Cu}(\mathrm{OAc})_{2} \cdot \mathrm{H}_{2} \mathrm{O} 1.0$ equiv

dioxane $(0.15 \mathrm{M})$

$100^{\circ} \mathrm{C}, 24 \mathrm{~h}$

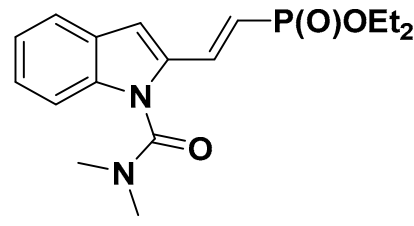

3 ao, $93 \%$<smiles>[R]C([R])=C([R])c1cc2ccccc2n1C(=O)N(C)C</smiles><smiles>CN(C)C(=O)n1c(/C=C/C#N)cc2ccccc21</smiles>

3ap, $56 \%$

Scheme 28. Ruthenium-catalyzed C2-H activation with active olefins.

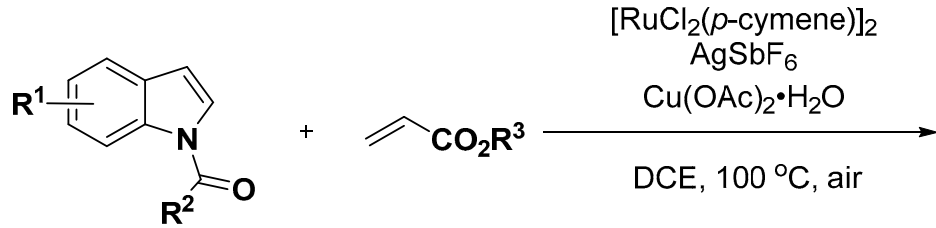

$\mathrm{R}^{1}=\mathrm{H}$, halogen, MeO...

$\mathrm{R}^{2}=\mathrm{Me}, \mathrm{Ph} \ldots$

$\mathrm{R}^{3}=\mathrm{Me}, \mathrm{Et}, \mathrm{Ph}$, cyclohexyl, napthyl...<smiles>[R1]C=CC=Cc1cc2cc[R1]([R])cc2n1C([R])=O</smiles>

up to $99 \%$ yields

Scheme 29. Ruthenium-catalyzed C2-H activation with unsaturated esters.<smiles>[R][X]c1ccc2c(C(=O)O)cn(CCCC=CC(=O)O[R])c2c1</smiles>

$\mathrm{R}=\mathrm{H}$, halogen $\mathrm{R}^{\prime}=\mathrm{H}, \mathrm{Me}, \mathrm{Et}, \mathrm{Bn}, t-\mathrm{Bu} . .$.

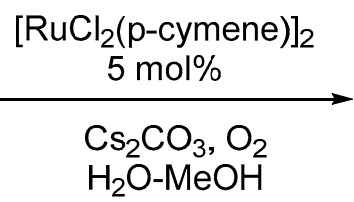

up to $97 \%$ yields

Scheme 30. Ruthenium-catalyzed C2-H activation to afford tetrahydropyridoindoles.

In 2014, Dong [56] developed a simple and highly efficient Ru-catalyzed C3 alkylation of indoles with $\alpha, \beta$-unsaturated ketones without the chelation assistance (Scheme 31). Besides indoles, a broad scope of substances, such as pyrroles and other azoles, are exhibited with further applications leading to 3,4-fused tricyclic indoles.

Dong [57] also reported direct alkylation or cascade cyclization reactions on C3 of indoles (Scheme 32). With the $\mathrm{Ru}\left(\mathrm{PPh}_{3}\right)_{3} \mathrm{Cl}_{2}$ catalyst, the reaction provides $\mathrm{C} 3$-substituted $\beta$-ketone indoles and $\left[\mathrm{Ru}(\mathrm{p} \text {-cymene }) \mathrm{Cl}_{2}\right]_{2}$ affords 5,12-dihydrobenzo [6,7] cyclohepta [1,2-b] indoles. The selective pathway may be attributed to the difference in binding affinity of a metal center with but-3-en-2-ol.

Allylation reactions are universally researched in organic chemistry. Bruneau [58] in 2009 constructed a tertiary carbon center on $\mathrm{C} 3$ of indole utilizing dimethyl allyl alcohol with the synthesized catalyst complex C, resulting in the formation of the branched product as a major compound. In 2007, Pregosin [59] developed a regioselective allylation of a variety of indole compounds using allyl alcohol as substrate with a novel $\mathrm{Ru}(\mathrm{IV})$ salt under mild conditions (Scheme 33). 


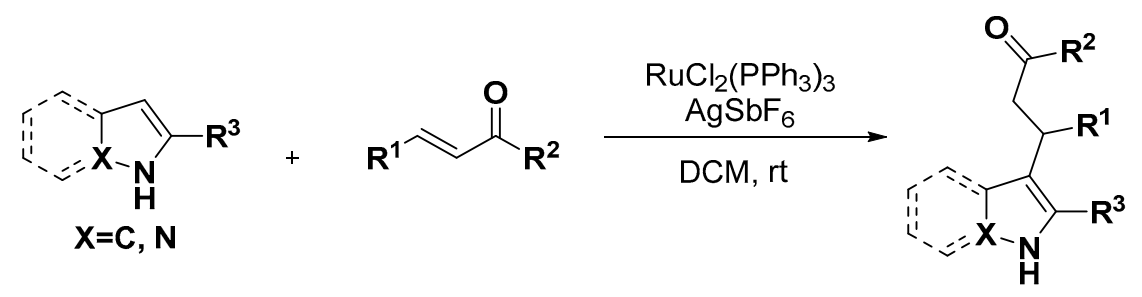

$\mathrm{R} 1=$ alkyl, phenyl, $\mathrm{Ph}(\mathrm{O}) \ldots$

R2= alkyl, phenyl...

$\mathrm{R} 3=\mathrm{H}, \mathrm{Me}$

up to $96 \%$ yields

Scheme 31. Ruthenium-catalyzed C3-H activation with unsaturated esters.<smiles>[R][R]1ccc2cc([R])[nH]c2c1</smiles>

$\mathrm{R}^{1}=\mathrm{H}, \mathrm{Ph}$

$\mathrm{R}^{2}=\mathrm{H}, \mathrm{OAC} \ldots$<smiles>c1ccc(-c2cc3ccccc3[nH]2)cc1</smiles>

$\mathrm{Ru}\left(\mathrm{PPh}_{3}\right)_{3} \mathrm{Cl}_{2} 5 \mathrm{~mol} \%$

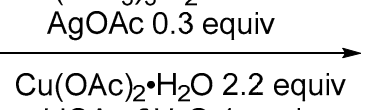

LiOAc $2 \mathrm{H}_{2} \mathrm{O} 1$ equiv DCE, $130^{\circ} \mathrm{C}$<smiles>[R]c1c(CCC(C)=O)c2c(n1[R])C=C[R1]C=C2</smiles>

up to $83 \%$ yields

$\left[\mathrm{Ru}(\mathrm{p} \text {-cymene }) \mathrm{Cl}_{2}\right]_{2} 5 \mathrm{~mol} \%$

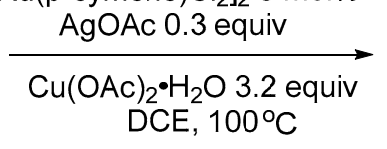

Scheme 32. Ruthenium-catalyzed C3-H activation with allylic alcohol.

\section{Bruneau's work}

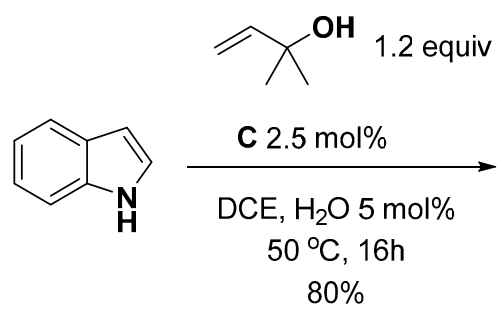

Pregosin's work<smiles>[R]c1ccc2[nH]ccc2c1</smiles><smiles>[R]c1ccc2[nH]ccc2c1</smiles><smiles>[R]c1ccc2[nH]ccc2c1</smiles><smiles>C=CC(C)(C)c1c[nH]c2ccccc12</smiles><smiles>CC(C)=CCc1c[nH]c2ccccc12</smiles>

$95: 5$<smiles>Cc1c(C)c2c(C)c(c1C)[PH](C)(C)c1ccccc1S(=O)(=O)O2</smiles>

complex C

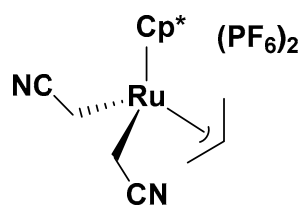

3

Scheme 33. Ruthenium-catalyzed C3-H activation with allylic alcohol.

In 2010, the reaction of indoles with amines was studied by Beller and his coworkers (Scheme 34). Shvo 1 was reported as a catalyst to promote the alkylation on C3 of indoles with alkylamine [60]. Such an 
alkylation process, based on the so-called "borrowing hydrogen methodology", which is initially dehydrogenated before undergoing a functionalization reaction, followed by a re-hydrogenation reaction, led to ammonia as the only side product.<smiles>[R]c1c[nH]c2ccc(C)cc12</smiles>

Shvo 1

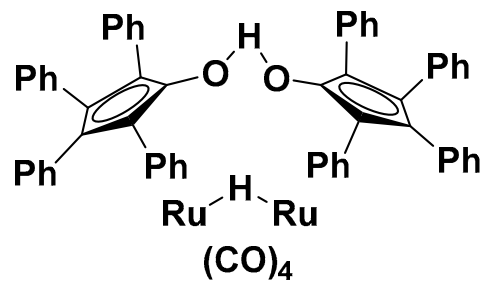

Scheme 34. Ruthenium-catalyzed C3-H alkylation with alkylated amines.

In the same year, Che's group [61] reported work involving ruthenium-catalyzed alkylation of indoles with tertiary amines by $\mathrm{C}\left(\mathrm{sp}^{3}\right)-\mathrm{H}$ Bond activation and dehydrogenation coupling (Scheme 35). Interestingly, products with one carbon insertion between the para-site of the phenyl ring and C3 of the indoles were detected at good yields. A mechanism proposed in the article shows that Ru catalyst is oxidized by peroxide before participating the oxidation from the $\mathrm{N}$-methyl compound to imine intermediate. Then, a molecular of formaldehyde is removed to form the one carbon insertion product with the presence of Lewis acid.

\section{Ru Cat.=[Ru(2,6-Cl $2 \mathrm{tpp}) \mathrm{CO}] ;$ tpp=tetraphenylporphinato)}

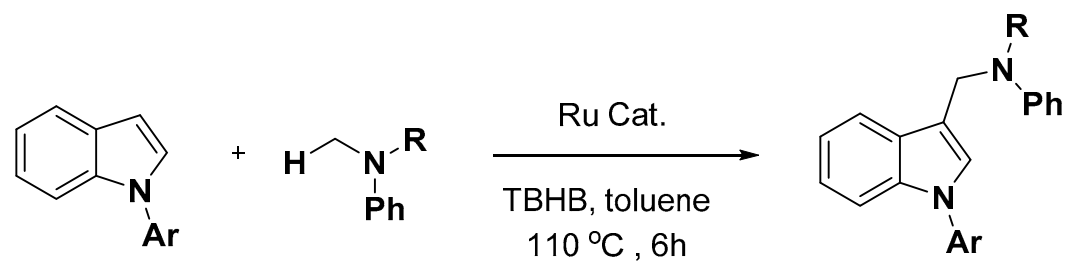

$\mathrm{Ar}=\mathrm{Ph}, \mathrm{MePh}, \mathrm{MeOPh} .$. $\mathrm{R}=\mathrm{Me}, n-\mathrm{Bu} .$.<smiles>[R]N(C)c1ccccc1</smiles>

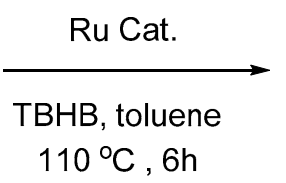

$110^{\circ} \mathrm{C}, 6 \mathrm{~h}$ up to $82 \%$ yields

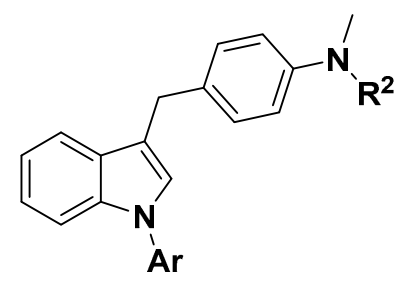

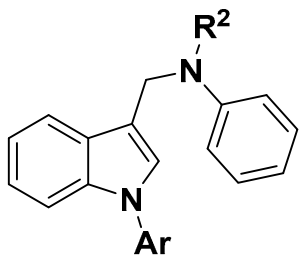

Scheme 35. Ruthenium-catalyzed C3-H activation with methylated amines.

There are also additional $\mathrm{C}-\mathrm{H}$ functionalization reactions on $\mathrm{C} 2$ or $\mathrm{C} 3$ of indoles. Prabhu [62] selectively functionalize C-2 in the presence of highly reactive C-3 in indole derivatives using $\left[\mathrm{Ru}(p \text {-cymene }) \mathrm{Cl}_{2}\right]_{2}$ catalyst, with a conjugate addition product instead of Heck-type product or $\mathrm{C} 3$ substitution achieved (Scheme 36). Wu [63] developed a Ru-catalyzed carbonylative coupling of indoles and aryl iodides for the synthesis of 3-acylindoles. However, no desired products were detected when indole or 3-methyl- $1 \mathrm{H}$-indole was used as the substrate, indicating that the $\mathrm{C} 2$ methyl group of indoles played a crucial role in this $\mathrm{C}-\mathrm{H}$ activation reaction. 
<smiles>O=C(c1ccccc1)n1ccc2cc[R]cc21</smiles><smiles>[R]N1C(=O)C=CC1=O</smiles><smiles>[R][C]1C=CC=C2C=C(C3CC(=O)N([R])C3=O)C(=O)N12</smiles>

up to $78 \%$ yields

$\mathrm{R}=\mathrm{H}$, halogen, $\mathrm{Ph}, \mathrm{MeO}, \mathrm{CO}_{2} \mathrm{Me}$

$\mathrm{R}^{\prime}=\mathrm{Bn}, \mathrm{Et}, \mathrm{Ph}$

$$
\begin{gathered}
\frac{\left[\mathrm{RuCl}_{2}(p-\text { cymene })\right]_{2}}{\mathrm{AgSbF}_{6}} \\
\mathrm{Cu}(\mathrm{OAc})_{2} \cdot \mathrm{H}_{2} \mathrm{O}
\end{gathered}
$$

Bz<smiles>Ic1cc[R]cc1</smiles>

$\left[\operatorname{RuCl}_{2}(p \text {-cymene })\right]_{2}$ $\mathrm{ZnBr}_{2}$, TFA

HFIP, $100^{\circ} \mathrm{C}, 30 \mathrm{~h}$<smiles>[R]c1ccc(C(=O)c2c(C)[nH]c3c2C=C[R]C=C3)cc1</smiles>

up to $66 \%$ yields

$\mathrm{R}=\mathrm{H}, \mathrm{Me}$

$\mathrm{R}^{\prime}=\mathrm{H}, \mathrm{Me}, \mathrm{Bn}, \mathrm{MeO}, \mathrm{F}, \mathrm{CF}_{3}, \mathrm{COOMe}$

Scheme 36. Ruthenium-catalyzed C3-H activation with other substrates.

\section{2. $\mathrm{C}-\mathrm{H}$ Activation on $\mathrm{C} 4-\mathrm{C} 7$}

There are fewer reports on ruthenium-catalyzed $\mathrm{C}-\mathrm{H}$ functionalization of indoles on the $\mathrm{C} 4$ to $\mathrm{C}$. However, the use of ortho-directing groups has become the preeminent strategy. With the assistance of an aldehyde group on C3, Prabhu [64] achieved vinylation on C4 of indoles under mild conditions (Scheme 37). In this study, it was found that the reaction may involve a six membered transition state that leads to the expected 4-substituted indoles. Many sorts of olefins including $\alpha, \beta$-unsaturated esters, cyano olifins, or vinyl phosphorate can proceed in good yields.<smiles>[R]#CC=c1ccccc1=CC=O</smiles>

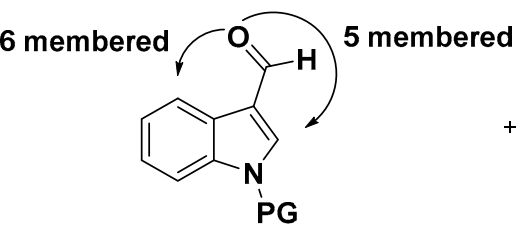

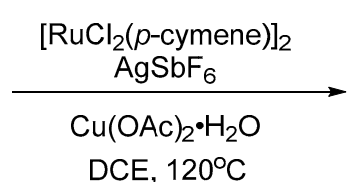

DCE, $120^{\circ} \mathrm{C}$

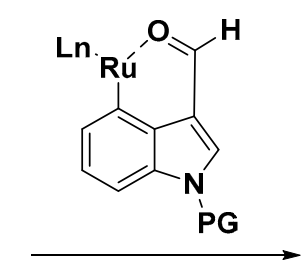<smiles>[R]C=Cc1cccc2c1c(C=O)cn2Cc1ccccc1</smiles><smiles>[R]OC(=O)/C=C/c1cccc2c1c(C=O)cn2P(=O)=O</smiles>

Scheme 37. Ruthenium-catalyzed $\mathrm{C} 4-\mathrm{H}$ activation with assistance of carboxylic acid.

Frost [65] achieved remote C-6 selective ruthenium-catalyzed C-H alkylation of pyrimidinyl-indole derivatives via a $\mathrm{C} 2$ cyclometallation $\sigma$-activation pathway with the assistance of an ancillary directing group at the $\mathrm{C} 3$ position (Scheme 38). Fukui index was calculated in this work indicating that the coordination and $\mathrm{C}-\mathrm{H}$ activation of the $\mathrm{Ru}$ at $\mathrm{C} 2$ gives the most active $\mathrm{C}-\mathrm{H}$ at $\mathrm{C} 6$. A mechanism study shows that the reaction is involved in a free radical process (Scheme 39). First of all, The proposed catalytically active monomer $\left[\mathrm{RuCl}_{2}(p\right.$-cymene $\left.)\right]$ is formed by breaking apart the dimer using $\mathrm{KOAc}$. 
Then, carboxylate-assisted cyclometallation at C2 occurs, including a proposed ring slip of the para-cymene to accommodate the primary and ancillary directing groups. Tertiary alkyl radical is created by the $\mathrm{Ru}(\mathrm{II})$ via single electron transfer before the cyclometalated species being attacked by the alkyl radical at the most activated vacant position, C6. After that, redox rearomatization takes place using the $\mathrm{Ru}(\mathrm{III})$ generated previously and an equivalent of potassium acetate. Protodemetalation then occurs using $\mathrm{AcOH}$ to give the $\mathrm{C} 6 \mathrm{C}-\mathrm{H}$ alkylated product (4a).<smiles>CCOC(=O)C(C)(C)c1ccc2c(C(C)(C)C(=O)OCC)cn(-c3ncccn3)c2c1</smiles>

Scheme 38. Ruthenium-catalyzed C6-H activation with assistance of carboxylic acid.

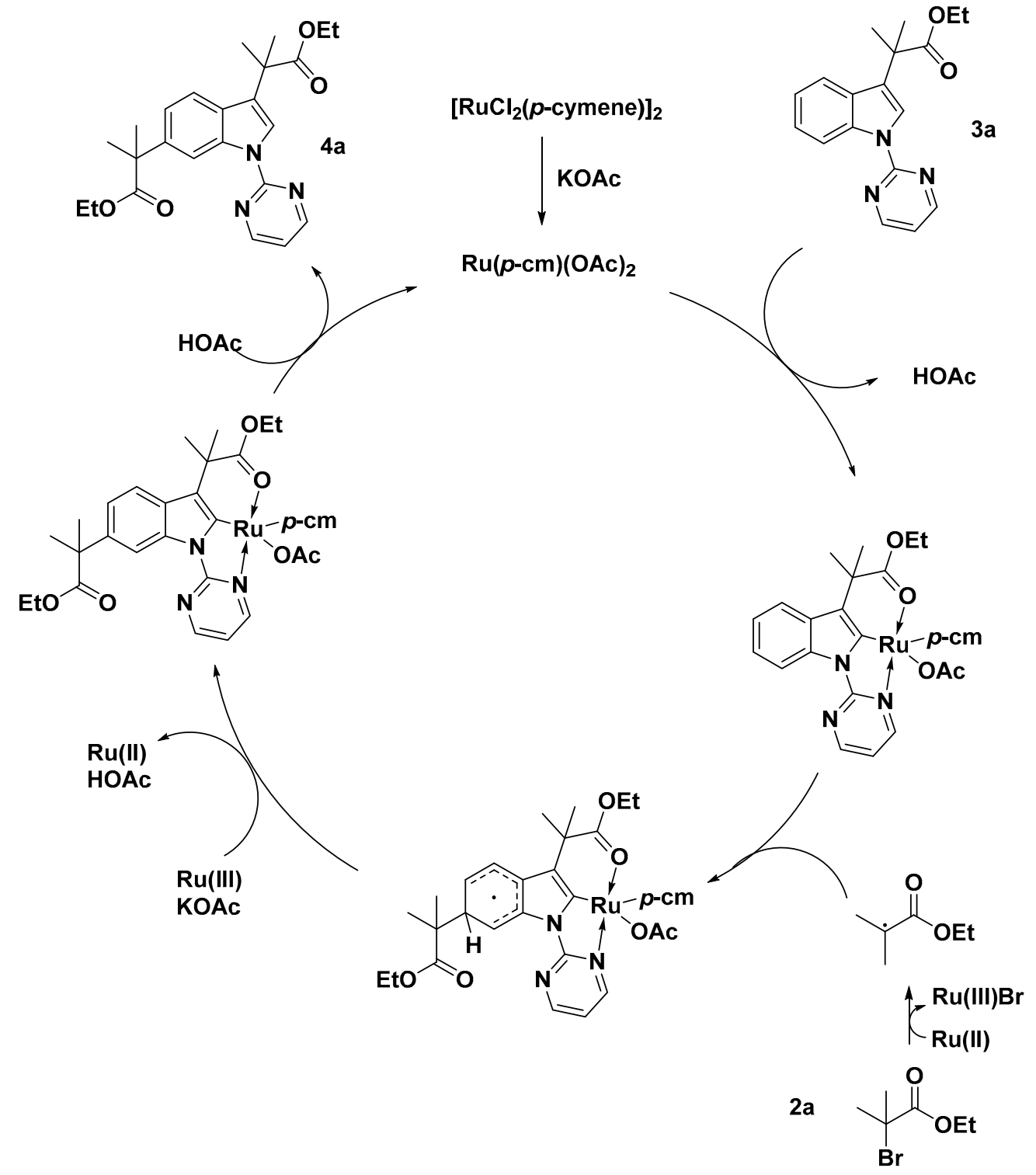

Scheme 39. Proposed reaction mechanism. 
With the assistance of the carboxyl group on the $\mathrm{C} 5$ position of indoles, $\mathrm{C}-\mathrm{H}$ functionalization on $\mathrm{C} 4$ and $\mathrm{C} 6$ of indole scaffolds can be achieved. Larrosa's group developed a Ru-catalyzed C-H arylation reaction on indole carboxylic acids allowing access to C7-, C6-, C5-, C4-arylated indole compounds [66]. In addition, Echavarren [67] discovered ruthenium-catalyzed ortho-alkynylation of benzoic acids with bromoalkynes under mild conditions (Scheme 40). In one example of this work, $1 H$-indole-5-carboxylic acid was alkynylated to give the double alkynylation products in moderate yield.

\section{Larrosa's work}

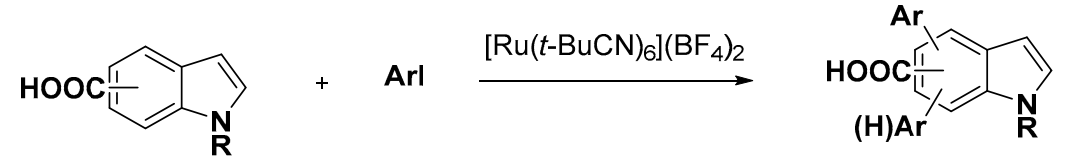

$\mathrm{Ar}=\mathrm{MePh}, \mathrm{MeOPh}, \mathrm{PhOPh}, \mathrm{FPh}, \mathrm{CF}_{3} \mathrm{Ph}, \mathrm{NO}_{2} \mathrm{Ph} \ldots \quad$ up to $92 \%$ yields $\mathrm{R}=\mathrm{Me}, \mathrm{PMP} \ldots$

Echavarren's work

HOOC<smiles>Cc1ccc2[nH]ccc2c1</smiles><smiles>S=[In]C#CBr</smiles><smiles>CC(C)C#Cc1cc2[nH]ccc2c(C#CC(C)C)c1C(=O)O</smiles>

Scheme 40. Ruthenium-catalyzed C-H activation with the assistance of C5 carboxylic acid.

C7 functionalization usually needs directing group. In 2016, Miura reported a C7 C-H activation reaction on indoles with the assistance of pyrimidine [68] (Scheme 41). This work demonstrated that $\mathrm{N}$-pyridylindoles underwent regioselective acetoxylation, which is expected to be applicable to a variety of dehydrogenative $\mathrm{C}-\mathrm{O}$ coupling reactions.<smiles>[Y]1cccnc1-n1c(-c2ccccc2)cc2ccccc21</smiles>

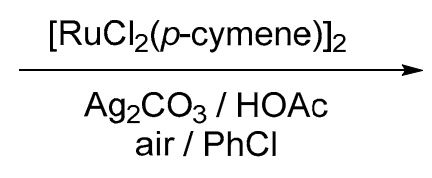<smiles>CC(=O)Oc1cccc2cc(-c3ccccc3)n(-c3nccc[Y]3C(=O)O)c12</smiles>

$\mathbf{Y}=\mathbf{N}$ or $\mathbf{C}$

Scheme 41. Ruthenium-catalyzed C7-H activation to construct $\mathrm{C}-\mathrm{O}$ bond.

In this year, Ackermann [69] disclosed the first ruthenium bicarboxylate-catalyzed C7-H activation of indoles via a weak coordinated unfavorable six membered ruthenacycle intermediate with pivaloyl directing group (Scheme 42). Sulfonamidation with azide as well as vinylization with unsaturated esters were reported in this work. Notable features of this strategy include unprecedented carboxylate-assisted ruthenium-catalyzed $\mathrm{C} 7-\mathrm{H}$ activation of indoles and expedient $\mathrm{C} 7-\mathrm{H}$ activations enabling amidations and alkenylations under exceedingly mild conditions. 
<smiles></smiles>
$\mathrm{TsN}_{3}$ H Piv<smiles>Pn1cccc2cc[nH+]c1-2</smiles>

\section{$\mathbf{R}-\mathbf{N}_{\mathbf{3}}$}

$\mathrm{Ru}(\mathrm{OAc})_{2}(p$-cymene) 10 (mol\%)

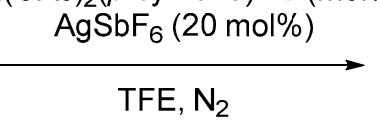

$\mathrm{Ru}(\mathrm{OAc})_{2}(p$-cymene) 10 (mol\%) $\mathrm{AgSbF}_{6}(20 \mathrm{~mol} \%)$<smiles>N#[PH]n1ccc2ccccc21</smiles><smiles>[R]OC(=O)C=C</smiles><smiles>[R]Nc1cccc2ccn(P)c12</smiles>

\section{$\mathrm{R}=\mathrm{Ts}, \mathrm{PhSO}_{2}, \mathrm{Ms}$.} up to $81 \%$ yields

Scheme 42. C7-H activation with the chelation of N-Piv and ruthenium.

\section{Summary}

The importance of indoles as valuable structural subunits in pharmaceuticals, natural products, and biologically active compounds means that new synthetic methods are being perpetually developed. The last two decades have seen a remarkable development of ruthenium-catalyzed $\mathrm{C}-\mathrm{H}$ activations for the synthesis of indole derivatives. There are still many challenges to overcome, such as the control of regioselectivity at other $\mathrm{C}-\mathrm{H}$ sites than at the ortho-position of directing groups or the development of new directing groups. Moreover, installation and removal of directing auxiliaries decrease the overall efficiency of the $\mathrm{C}-\mathrm{H}$ activation process. More importantly, enantioselective $\mathrm{C}-\mathrm{H}$ functionalization are highly desired to produce indole derivatives, and the relevant methodologies should also be paid considerable attention in this area. Therefore, further developments are expected to be able to address these questions.

Author Contributions: Design, C.L. and Y.Z.; writing—original draft preparation, H.Z. and S.Z.; writing-review and editing, H.Z., S.Z. and H.L.; editing, C.L. and Y.Z. All authors have read and agreed to the published version of the manuscript.

Funding: We are grateful to the National Natural Science Foundation of China (No. 81620108027, 21632008 and 91229204), the Strategic Priority Research Program of the Chinese Academy of Sciences (XDA12050411 and XDA12020375) and the Youth Innovation Promotion Association CAS for financial support.

Conflicts of Interest: The author declares no conflict of interest.

\section{References}

1. Gadelha, M.N.R.; Bronstein, M.D.; Brue, T.; Coculescu, M.; Fleseriu, M.; Guitelman, M.; Pronin, V.; Raverot, G.; Shimon, I.; Lievre, K.K.J.L.D.; et al. Pasireotide versus continued treatment with octreotide or lanreotide in patients with inadequately controlled acromegaly (PAOLA): A randomised, phase 3 trial. Lancet Diabetes Endocrinol. 2014, 2, 875-884. [CrossRef]

2. Modlin, I.M.; Pavel, M.; Kidd, M.; Gustafsson, B.I. Review article: Somatostatin analogues in the treatment of gastroenteropancreatic neuroendocrine (carcinoid) tumours. Aliment. Pharmacol. Ther. 2010, 31, 169-188. [CrossRef]

3. Watson, P.A.; Arora, V.K.; Sawyers, C.L. Emerging mechanisms of resistance to androgen receptor inhibitors in prostate cancer. Nat. Rev. Cancer 2015, 15, 701-711. [CrossRef] [PubMed] 
4. Wang, S.; Cang, S.; Liu, D. Third-generation inhibitors targeting EGFR T790M mutation in advanced non-small cell lung cancer. J. Hematol. Oncol. 2016, 9, 34. [CrossRef] [PubMed]

5. Greig, S.L. Osimertinib: First Global Approval. Drugs 2016, 76, 263-273. [CrossRef]

6. Das, A.; Durrant, D.; Salloum, F.N.; Xi, L.; Kukreja, R.C. PDE5 inhibitors as therapeutics for heart disease, diabetes and cancer. Pharmacol. Ther. 2015, 147, 12-21. [CrossRef] [PubMed]

7. Hoy, S.M. Elexacaftor/Ivacaftor/Tezacaftor: First Approval. Drugs 2019, 79, 2001-2007. [CrossRef]

8. Dai, W.; Zhang, B.; Jiang, X.-M.; Su, H.; Li, J.; Zhao, Y.; Xie, X.; Jin, Z.; Peng, J.; Liu, F.; et al. Structure-based design of antiviral drug candidates targeting the SARS-CoV-2 main protease. Science 2020, 368, 1331. [CrossRef]

9. Tan, D.-X.; Zhou, J.; Liu, C.-Y.; Han, F.-S. Enantioselective Total Synthesis and Absolute Configuration Assignment of (+)-Tronocarpine Enabled by an Asymmetric Michael/Aldol Reaction. Angew. Chem. Int. Ed. 2020, 59, 3834-3839. [CrossRef]

10. Eicher, T.; Hauptmann, S. The Chemistry of Heterocycles: Structures, Reactions, Synthesis, and Applications; John Wiley \& Sons: Hoboken, NJ, USA, 2003.

11. Yeung, C.S.; Dong, V.M. Catalytic dehydrogenative cross-coupling: Forming carbon-carbon bonds by oxidizing two carbon-hydrogen bonds. Chem. Rev. 2011, 111, 1215-1292. [CrossRef]

12. Li, Y.; Qi, Z.; Wang, H.; Yang, X.; Li, X. Ruthenium(II)-Catalyzed C-H Activation of Imidamides and Divergent Couplings with Diazo Compounds: Substrate-Controlled Synthesis of Indoles and 3H-Indoles. Angew. Chem. Int. Ed. 2016, 55, 11877-11881. [CrossRef]

13. Yang, Q.; Wu, C.; Zhou, J.; He, G.; Liu, H.; Zhou, Y. Highly selective C-H bond activation of $\mathrm{N}$-arylbenzimidamide and divergent couplings with diazophosphonate compounds: A catalyst-controlled selective synthetic strategy for 3-phosphorylindoles and 4-phosphorylisoquinolines. Org. Chem. Front. 2019, 6, 393-398. [CrossRef]

14. Ackermann, L.; Lygin, A.V. Cationic Ruthenium(II) Catalysts for Oxidative C-H/N-H Bond Functionalizations of Anilines with Removable Directing Group: Synthesis of Indoles in Water. Org. Lett. 2012, 14, 764-767. [CrossRef] [PubMed]

15. Liao, Y.; Wei, T.; Yan, T.; Cai, M. Recyclable [Ru2Cl3(p-cymene)2][PF6]/Cu(OAc)2/PEG-400/H2O system for oxidative annulation of alkynes by aniline derivatives: Green synthesis of indoles. Tetrahedron 2017, 73, 1238-1246. [CrossRef]

16. Allu, S.; Kumara Swamy, K.C. Ruthenium-Catalyzed Oxidative Annulation of 6-Anilinopurines with Alkynes via C-H Activation: Synthesis of Indole-Substituted Purines/Purine Nucleosides. Adv. Syn. Catal. 2015, 357, 2665-2680. [CrossRef]

17. Borthakur, S.; Sarma, B.; Gogoi, S. Ruthenium(II)-Catalyzed Oxidative Double C-H Activation and Annulation Reaction: Synthesis of Indolo[2,1-a]isoquinolines. Org. Lett. 2019, 21, 7878-7882. [CrossRef] [PubMed]

18. Chen, X.; Cui, X.; Bai, L.; Wang, Y.; Xie, Y.; Wang, S.; Zhai, R.; Zhao, K.; Kong, D.; Li, Y. Ruthenium(II)-Catalyzed C-H Bond [3+2] Annulation of N-Nitrosoanilines with Alkynes in Water. Asian J. Org. Chem. 2019, 8, 2209-2212. [CrossRef]

19. Intrieri, D.; Carminati, D.M.; Zardi, P.; Damiano, C.; Manca, G.; Gallo, E.; Mealli, C. Indoles from Alkynes and Aryl Azides: Scope and Theoretical Assessment of Ruthenium Porphyrin-Catalyzed Reactions. Chem. Eur. J. 2019, 25, 16591-16605. [CrossRef] [PubMed]

20. Xu, F.; Li, Y.-J.; Huang, C.; Xu, H.-C. Ruthenium-Catalyzed Electrochemical Dehydrogenative Alkyne Annulation. ACS Catal. 2018, 8, 3820-3824. [CrossRef]

21. Xia, X.-D.; Xuan, J.; Wang, Q.; Lu, L.-Q.; Chen, J.-R.; Xiao, W.-J. Synthesis of 2-Substituted Indoles through Visible Light-Induced Photocatalytic Cyclizations of Styryl Azides. Adv. Syn. Catal. 2014, 356, 2807-2812. [CrossRef]

22. Wang, C.H.; Li, Y.H.; Yang, S.D. Autoxidation Photoredox Catalysis for the Synthesis of 2-Phosphinoylindoles. Org. Lett. 2018, 20, 2382-2385. [CrossRef]

23. Wu, C.; Zhou, J.; He, G.; Li, H.; Yang, Q.; Wang, R.; Zhou, Y.; Liu, H. Ruthenium(ii)-catalyzed selective $\mathrm{C}-\mathrm{H}$ bond activation of imidamides and coupling with sulfoxonium ylides: An efficient approach for the synthesis of highly functional 3-ketoindoles. Org. Chem. Front. 2019, 6, 1183-1188. [CrossRef]

24. Panferova, L.I.; Smirnov, V.O.; Levin, V.V.; Kokorekin, V.A.; Struchkova, M.I.; Dilman, A.D. Synthesis of 3-Fluoroindoles via Photoredox Catalysis. J. Org. Chem. 2017, 82, 745-753. [CrossRef] [PubMed] 
25. Cho, C.S.; Kim, J.H.; Kim, T.-J.; Shim, S.C. Ruthenium-catalyzed heteroannulation of anilines with alkanolammonium chlorides leading to indoles. Tetrahedron 2001, 57, 3321-3329. [CrossRef]

26. Sathishkumar, P.N.; Prabha, P.S.; Bhuvanesh, N.S.P.; Karvembu, R. Tuning acylthiourea ligands in Ru(II) catalysts for altering the reactivity and chemoselectivity of transfer hydrogenation reactions, and synthesis of 3-isopropoxy-1H-indole through a new synthetic approach. J. Organomet. Chem. 2020, 908, 121087. [CrossRef]

27. Manna, M.K.; Bairy, G.; Jana, R. Sterically Controlled Ru(II)-Catalyzed Divergent Synthesis of 2-Methylindoles and Indolines through a C-H Allylation/Cyclization Cascade. J. Org. Chem. 2018, 83, 8390-8400. [CrossRef] [PubMed]

28. Lee, H.; Yi, C.S. Catalytic Synthesis of Substituted Indoles and Quinolines from the Dehydrative C-H Coupling of Arylamines with 1,2- and 1,3-Diols. Organometallics 2016, 35, 1973-1977. [CrossRef] [PubMed]

29. Colby, D.A.; Bergman, R.G.; Ellman, J.A. Rhodium-Catalyzed C-C Bond Formation via Heteroatom-Directed C-H Bond Activation. Chem. Rev. 2010, 110, 624-655. [CrossRef]

30. Ackermann, L.; Lygin, A.V. Ruthenium-catalyzed direct C-H bond arylations of heteroarenes. Org. Lett. 2011, 13, 3332-3335. [CrossRef]

31. Sollert, C.; Devaraj, K.; Orthaber, A.; Gates, P.J.; Pilarski, L.T. Ru-Catalysed C H Arylation of Indoles and Pyrroles with Boronic Acids: Scope and Mechanistic Studies. Chem. Eur. J. 2015, 21, 5380-5386. [CrossRef]

32. Nareddy, P.; Jordan, F.; Szostak, M. Ruthenium(II)-Catalyzed Direct C-H Arylation of Indoles with Arylsilanes in Water. Org. Lett. 2018, 20, 341-344. [CrossRef] [PubMed]

33. Ackermann, L.; Tonin, M.; Zell, D.; Müller, V. Ruthenium(II)-Catalyzed C-H Methylation with Trifluoroborates. Synthesis 2016, 49, 127-134. [CrossRef]

34. Chan, W.-W.; Yeung, S.-H.; Zhou, Z.; Chan, A.S.C.; Yu, W.-Y. Ruthenium Catalyzed Directing Group-Free C2-Selective Carbenoid Functionalization of Indoles by $\alpha$-Aryldiazoesters. Org. Lett. 2010, 12, 604-607. [CrossRef]

35. Ciszewski, Ł.W.; Durka, J.; Gryko, D. Photocatalytic Alkylation of Pyrroles and Indoles with $\alpha$-Diazo Esters. Org. Lett. 2019, 21, 7028-7032. [CrossRef] [PubMed]

36. Furst, L.; Matsuura, B.S.; Narayanam, J.M.R.; Tucker, J.W.; Stephenson, C.R.J. Visible Light-Mediated Intermolecular $\mathrm{C}-\mathrm{H}$ Functionalization of Electron-Rich Heterocycles with Malonates. Org. Lett. 2010, 12, 3104-3107. [CrossRef] [PubMed]

37. Erdenebileg, U.; Demissie, T.B.; Hansen, J.H. Visible-Light Photocatalytic Double C-H Functionalization of Indoles: A Synergistic Experimental and Computational Study. Synlett 2017, 28, 907-912. [CrossRef]

38. De Montellano, P.R.O. Cytochrome P450: Structure, Mechanism, and Biochemistry; Springer Science \& Business Media: Berlin/Heidelberg, Germany, 2005.

39. Zhou, Y.; Wang, J.; Gu, Z.; Wang, S.; Zhu, W.; Acena, J.L.; Soloshonok, V.A.; Izawa, K.; Liu, H. Next Generation of Fluorine-Containing Pharmaceuticals, Compounds Currently in Phase II-III Clinical Trials of Major Pharmaceutical Companies: New Structural Trends and Therapeutic Areas. Chem. Rev. 2016, 116, 422-518. [CrossRef]

40. Nagib, D.A.; MacMillan, D.W. Trifluoromethylation of arenes and heteroarenes by means of photoredox catalysis. Nature 2011, 480, 224-228. [CrossRef]

41. Iqbal, N.; Choi, S.; Ko, E.; Cho, E.J. Trifluoromethylation of heterocycles via visible light photoredox catalysis. Tetrahedron Lett. 2012, 53, 2005-2008. [CrossRef]

42. Straathof, N.J.; Gemoets, H.P.; Wang, X.; Schouten, J.C.; Hessel, V.; Noel, T. Rapid trifluoromethylation and perfluoroalkylation of five-membered heterocycles by photoredox catalysis in continuous flow. ChemSusChem 2014, 7, 1612-1617. [CrossRef]

43. Nakao, Y.; Hiyama, T. Silicon-based cross-coupling reaction: An environmentally benign version. Chem. Soc. Rev. 2011, 40, 4893-4901. [CrossRef]

44. Klare, H.F.; Oestreich, M.; Ito, J.; Nishiyama, H.; Ohki, Y.; Tatsumi, K. Cooperative catalytic activation of $\mathrm{Si}-\mathrm{H}$ bonds by a polar Ru-S bond: Regioselective low-temperature $\mathrm{C}-\mathrm{H}$ silylation of indoles under neutral conditions by a Friedel-Crafts mechanism. J. Am. Chem. Soc. 2011, 133, 3312-3315. [CrossRef] [PubMed]

45. Devaraj, K.; Sollert, C.; Juds, C.; Gates, P.J.; Pilarski, L.T. Ru-catalysed C-H silylation of unprotected gramines, tryptamines and their congeners. Chem. Commun. 2016, 52, 5868-5871. [CrossRef] 
46. Cadierno, V.; Francos, J.; Gimeno, J. Ruthenium/TFA-catalyzed regioselective C-3-alkylation of indoles with terminal alkynes in water: Efficient and unprecedented access to 3-(1-methylalkyl)-1H-indoles. Chem. Commun. 2010, 46, 4175-4177. [CrossRef]

47. Singh, K.S.; Sawant, S.G.; Dixneuf, P.H. Ruthenium(II)-Catalyzed Synthesis of Pyrrole- and Indole-Fused Isocoumarins by $\mathrm{C}-\mathrm{H}$ Bond Activation in DMF and Water. Chem CatChem 2016, 8, 1046-1050. [CrossRef]

48. Xie, Y.; Wu, X.; Li, C.; Wang, J.; Li, J.; Liu, H. Ruthenium(II)-Catalyzed Redox-Neutral [3+2] Annulation of Indoles with Internal Alkynes via C-H Bond Activation: Accessing a Pyrroloindolone Scaffold. J. Org. Chem. 2017, 82, 5263-5273. [CrossRef] [PubMed]

49. Thies, N.; Hrib, C.G.; Haak, E. Ruthenium-Catalyzed Functionalization of Pyrroles and Indoles with Propargyl Alcohols. Chem. Eur. J. 2012, 18, 6302-6308. [CrossRef] [PubMed]

50. Haak, E. Modern Annulation Strategies for the Synthesis of Cyclo[b]fused Indoles. Synlett 2018, 30, $245-251$. [CrossRef]

51. Li, B.; Ma, J.; Xie, W.; Song, H.; Xu, S.; Wang, B. Ruthenium-catalyzed regioselective C2 alkenylation of indoles and pyrroles via C-H bond functionalization. J. Org. Chem. 2013, 78, 9345-9353. [CrossRef]

52. Zhang, L.Q.; Yang, S.; Huang, X.; You, J.; Song, F. Aerobic Ru-catalyzed direct C2-olefination of N-heteroarenes with alkenes directed by a removable N-dimethylcarbamoyl group. Chem. Commun. 2013, 49, 8830-8832. [CrossRef]

53. Lanke, V.; Prabhu, K.R. Highly Regioselective C2-Alkenylation of Indoles Using the N-Benzoyl Directing Group: An Efficient Ru-Catalyzed Coupling Reaction. Org. Lett. 2013, 15, 2818-2821. [CrossRef] [PubMed]

54. Chen, W.; Li, H.J.; Li, Q.Y.; Wu, Y.C. Direct oxidative coupling of N-acyl pyrroles with alkenes by ruthenium(ii)-catalyzed regioselective C2-alkenylation. Org. Biomol. Chem. 2020, 18, 500-513. [CrossRef] [PubMed]

55. Jin, X.Y.; Xie, L.J.; Cheng, H.P.; Liu, A.D.; Li, X.D.; Wang, D.; Cheng, L.; Liu, L. Ruthenium-Catalyzed Decarboxylative C-H Alkenylation in Aqueous Media: Synthesis of Tetrahydropyridoindoles. J. Org. Chem. 2018, 83, 7514-7522. [CrossRef] [PubMed]

56. Li, S.S.; Lin, H.; Zhang, X.M.; Dong, L. Ruthenium-catalyzed direct C3 alkylation of indoles with alpha, beta-unsaturated ketones. Org. Biomol. Chem. 2015, 13, 1254-1263. [CrossRef]

57. Xia, Y.-Q.; Li, C.; Liu, M.; Dong, L. Ruthenium-Catalyzed Selective C-C Coupling of Allylic Alcohols with Free Indoles: Influence of the Metal Catalyst. Chem. Eur. J. 2018, 24, 5474-5478. [CrossRef]

58. Sundararaju, B.; Achard, M.; Demerseman, B.; Toupet, L.; Sharma, G.V.; Bruneau, C. Ruthenium(IV) complexes featuring P, O-chelating ligands: Regioselective substitution directly from allylic alcohols. Angew. Chem. Int. Ed. 2010, 49, 2782-2785. [CrossRef]

59. Zaitsev, A.B.; Gruber, S.; Pregosin, P.S. Fast, efficient Ru(IV)-catalysed regioselective allylation of indoles using allyl alcohol (without additives) under mild conditions. Chem. Commun. 2007, 4692-4693. [CrossRef]

60. Imm, S.; Bähn, S.; Tillack, A.; Mevius, K.; Neubert, L.; Beller, M. Selective Ruthenium-Catalyzed Alkylation of Indoles by Using Amines. Chem. Eur. J. 2010, 16, 2705-2709. [CrossRef]

61. Wang, M.-Z.; Zhou, C.-Y.; Wong, M.-K.; Che, C.-M. Ruthenium-Catalyzed Alkylation of Indoles with Tertiary Amines by Oxidation of a sp3 C-H Bond and Lewis Acid Catalysis. Chem. Eur. J. 2010, 16, 5723-5735. [CrossRef]

62. Lanke, V.; Bettadapur, K.R.; Prabhu, K.R. Site-Selective Addition of Maleimide to Indole at the C-2 Position: Ru(II)-Catalyzed C-H Activation. Org. Lett. 2015, 17, 4662-4665. [CrossRef]

63. Wang, Z.; Yin, Z.; Wu, X.F. 3-Acylindoles Synthesis: Ruthenium-Catalyzed Carbonylative Coupling of Indoles and Aryl Iodides. Org. Lett. 2017, 19, 4680-4683. [CrossRef]

64. Lanke, V.; Ramaiah Prabhu, K. Regioselective Synthesis of 4-Substituted Indoles via C-H Activation: A Ruthenium Catalyzed Novel Directing Group Strategy. Org. Lett. 2013, 15, 6262-6265. [CrossRef]

65. Leitch, J.A.; McMullin, C.L.; Mahon, M.F.; Bhonoah, Y.; Frost, C.G. Remote C6-Selective Ruthenium-Catalyzed C-H Alkylation of Indole Derivatives via $\sigma$-Activation. ACS Catal. 2017, 7, 2616-2623. [CrossRef]

66. Simonetti, M.; Cannas, D.M.; Panigrahi, A.; Kujawa, S.; Kryjewski, M.; Xie, P.; Larrosa, I. Ruthenium-Catalyzed $\mathrm{C}-\mathrm{H}$ Arylation of Benzoic Acids and Indole Carboxylic Acids with Aryl Halides. Chem. Eur. J. 2017, 23, 549-553. [CrossRef]

67. Tan, E.; Konovalov, A.I.; Fernandez, G.A.; Dorel, R.; Echavarren, A.M. Ruthenium-Catalyzed Peri- and Ortho-Alkynylation with Bromoalkynes via Insertion and Elimination. Org. Lett. 2017, 19, 5561-5564. [CrossRef] [PubMed] 
68. Okada, T.; Nobushige, K.; Satoh, T.; Miura, M. Ruthenium-Catalyzed Regioselective C-H Bond Acetoxylation on Carbazole and Indole Frameworks. Org. Lett. 2016, 18, 1150-1153. [CrossRef] [PubMed]

69. Choi, I.; Messinis, A.M.; Ackermann, L. C7-Indole Amidations and Alkenylations by Ruthenium(II) Catalysis. Angew. Chem. Int. Ed. 2020, 59, 12534-12540. [CrossRef]

Publisher's Note: MDPI stays neutral with regard to jurisdictional claims in published maps and institutional affiliations.

(C) 2020 by the authors. Licensee MDPI, Basel, Switzerland. This article is an open access article distributed under the terms and conditions of the Creative Commons Attribution (CC BY) license (http://creativecommons.org/licenses/by/4.0/). 